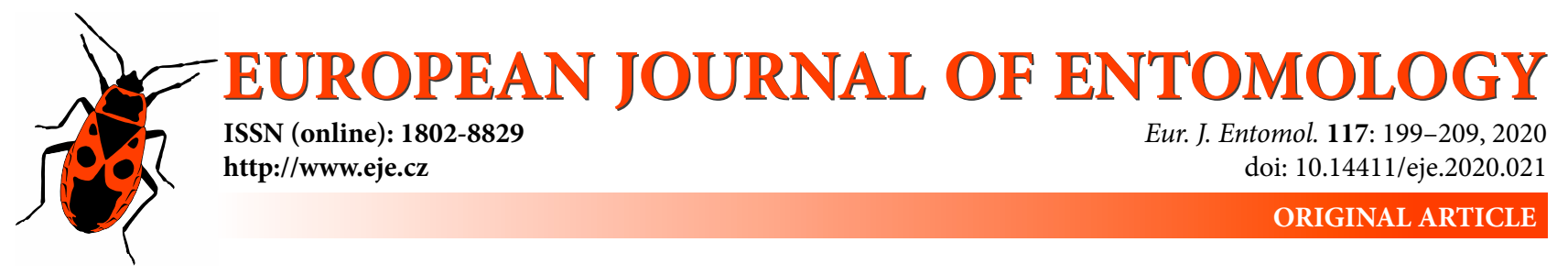

\title{
Ecological and molecular diversity of Eulachnini aphids (Hemiptera: Aphididae: Lachninae) on coniferous plants in Lithuania
}

\author{
JekATERINA HAVELKA, JuRIJ DANILOV and RimantAs RAKAUSKAS \\ Institute of Biosciences, Life Sciences Centre, Vilnius University, Saulètekio al. 7, LT-10257 Vilnius, Lithuania; \\ e-mails: jekaterina.havelka@gf.vu.It, jdanilovas@gmail.com, rimantas.rakauskas@gf.vu.It
}

\begin{abstract}
Key words. Hemiptera, Aphididae, Eulachnini, taxonomy, distribution, ecology, mitochondrial COI, nuclear EF-1a, molecular delimitation of species, Lithuania, Europe
\end{abstract}

\begin{abstract}
Based on research carried out from 2016 to 2018 there are twenty-six species of aphids of the tribe Eulachnini in Lithuania. Seventeen are members of the subgenus Cinara of the genus Cinara, three of the subgenus Cupressobium and two of the subgenus Schizolachnus. In addition, there are four species of the genus Eulachnus. Summarized information on the distribution and host specificity of Eulachnini in Lithuania is presented. Nine species were in all climatic regions of Lithuania: C. (Cinara) brauni, C. (Cinara) hyperophila, C. (Cinara) neubergi, C. (Cinara) piceicola, C. (Cinara) pinea, C. (Cinara) pini, C. (Cinara) pruinosa, C. (Cupressobium) cupressi and C. (Cupressobium) juniperi. Five species of Lithuanian Eulachnini inhabit host plants of the genus Picea, three live on Larix, thirteen on Pinus, one on Abies, one on Thuja and three on Juniperus. Cinara (Cinara) piniphila was recorded on Pinus mugo and C. (Cinara) nuda on Pinus heldreichii for the first time. Partial COI and EF-1a sequences of $C$. (Cinara) hyperophila, C. (Cinara) pilosa and C. (Cinara) piceicola were obtained for the first time. Partial sequences of mitochondrial (COI) and nuclear (EF-1a) DNA of Lithuanian samples were used to explore molecular diversity using NJ trees, Automatic Barcode Gap Discovery (ABGD), General Mixed Yule Coalescent (GMYC) and Poisson Tree Processes (PTP). Species delimitation using GMYC (both on COI and EF-1 $\alpha$ sequences), PTP (BI on COI) and ABGD (EF-1 $\alpha$ ) were the most consistent with traditional classifications. Pairwise between-species sample divergences (COI and EF-1 $\alpha$ fragments) of the samples of the species complex $C$. (Cinara) pinea - C. (Cinara) piniphila indicate it is composed of a single species. Of the species of aphids that live on conifers, there are seven species of the tribe Eulachnini that are likely to shortly colonize Lithuania.
\end{abstract}

\section{INTRODUCTION}

Aphids of the tribe Eulachnini Baker, 1920 (Hemiptera: Aphididae: Lachninae) are phloem feeding insects inhabiting plants of the families Pinaceae and Cupressaceae. They are adapted to feed on particular parts of their host plants. Of the species of Eulachnini, those of the genus Eulachnus del Guercio, 1909 and subgenus Schizolachnus Mordvilko, 1909 of the genus Cinara Curtis, 1835, prefer the needles of their host plants. Other species of the genus Cinara inhabit the bark of roots, trunks, branches, twigs and shoots (Binazzi \& Scheurer, 2009; Chen et al., 2016b; Albrecht, 2017; Blackman \& Eastop, 2019). Aphids of the tribe Eulachnini can cause serious damage in tree nurseries, parks, forests and cultivated areas (Watson et al., 1999; Hopmans \& Elms, 2013; Dara et al., 2019). The honeydew of these aphids, however, is the raw material for the so called "forest honey", which is an important commercial product in Europe (Binazzi \& Scheurer, 2009).

Forests cover approximately 30\% of Lithuania. Most consist of pine and spruce stands (https://www.forestgen. mi.lt). Nevertheless, information about the species of Eulachnini inhabiting coniferous plants in Lithuania consists mainly of fragmentary faunistic records reporting the presence of 19 species of this tribe (for details, see Rakauskas et al., 1992, 2008). Our pilot study in 2017 revealed the presence of 27 species of the tribe Eulachnini in Lithuania (Danilov et al., 2019). In the surrounding countries there are 34 species in Poland, 19 in Latvia, 21 in Belarus and 9 in the Kaliningrad region of Russia (Osiadacz \& Hałaj, 2009; Nieto Nafria et al., 2013; Hałaj \& Osiadacz, 2015; Wojciechowski et al., 2015). Forty species of Eulachnini are recorded in the Czech Republic, Slovakia and Austria (Holman \& Pintera, 1977; Holman, 2009; Nieto Nafria et al., 2013; Wojciechowski et al., 2016; Kanturski et al., 2017), which are in the southernmost part of the Central European floristic province according to Frey \& Lösch (2010). Lithuania is in the northernmost part of this floristic province. Due to global climate change, the Lithuanian fauna is expected to be enriched by species of Eulachnini from the South.

For the successful exploration of regional species diversity it is inevitable that DNA-based methods will have to be used in addition to ecological and morphological ones. These methods have proved to be a powerful tool 
in large-scale studies delimitating species and on speciation in the Eulachnini (Durak, 2011; Jousselin et al., 2013; Durak et al., 2014; Meseguer et al., 2015, 2017; Chen et al., 2016a, b). In this study, partial mitochondrial COI and nuclear EF-1 $\alpha$ sequences were used to investigate withinand between-species genetic diversity of species of Eulachnini in Lithuania. Despite its small area $\left(65,300 \mathrm{~km}^{2}\right)$, there are four climatic regions in Lithuania (Galvonaite et al., 2007) (Fig. 1). The coastal region is currently the coolest in summer and mildest in winter. The greatest seasonal fluctuation in temperature is recorded in the South eastern highlands. The wettest area is in the Coastal and Samogitian regions. Average annual precipitation in both these regions (1981-2010 data) is $850-950 \mathrm{~mm}$, whereas it is 550-650 in South eastern highlands (Galvonaite et al., 2013). According to Buivydaite et al. (2001), the least fertile soils are in the South eastern Highlands due to the predominance there of a thin layer of organic material (mostly arenosol and regosol soil types), and the most fertile are in the Middle Lithuanian Lowlands (mostly luvisols and cambisols). This accounts for the distribution of conifers in Lithuania, with pine stands most common in the South eastern highlands and spruce stands scattered mostly in the Middle Lithuanian and Samogitian regions (https://www. forestgen.mi.lt). In addition to natural stands of conifers, commercial forests, decorative plantings and gardens, also ensure a high host plant diversity. In this paper, we summarize information on the diversity, ecological and molecular specificity of aphids of the Eulachnini in Lithuania, present some taxonomic remarks and discuss the possible future development of the conifer-inhabiting aphid fauna in Lithuania.

\section{MATERIAL AND METHODS}

Aphid material for this study was collected by examining plants in situ (Blackman \& Eastop, 2000) from 2016 to 2018 (some unpublished samples from 2012 were also included) at 70 localities in all four climatic regions in Lithuania (Table 1, Fig. 1). Detailed information on the material sampled is presented in Table S1. Colonies of 17 species of Eulachnini (in bold in Table 1) were monitored monthly from September 2017 until October 2019 (monitoring sites shown as black circles in Fig. 1). Microscope slides of aphids mounted in Canada balsam were prepared according to Blackman \& Eastop (2000). For morphology based identification the keys of Blackman \& Eastop (2019), Heie

Table 1. Number of samples collected/number used in the molecular analysis of 26 species of the tribe Eulachnini collected from four climatic regions in Lithuania in 2016-2018. * - samples collected by Jan Havelka in 2012 and $2017, \mathrm{n}=1$ for each asterisk. C. - Cinara, Cu. - Cupressobium, S. - Schizolachnus, E. - Eulachnus. Species that were monitored monthly from September 2017 until October 2019 (monitoring sites shown as black circles in Fig. 1) are in bold.

\begin{tabular}{|c|c|c|c|c|c|c|}
\hline Species & Coastal & Samogitian & $\begin{array}{c}\text { Middle } \\
\text { Lithuanian } \\
\text { Lowlands }\end{array}$ & $\begin{array}{l}\text { Southeastern } \\
\text { Highlands }\end{array}$ & Host plants & Microhabitat \\
\hline \multicolumn{7}{|c|}{ Abies } \\
\hline C. (C.) pectinatae & $0 / 0$ & $0 / 0$ & $1 / 1$ & $0 / 0$ & koreana & Shoots \\
\hline \multicolumn{7}{|c|}{ Juniperus } \\
\hline C. (Cu.) juniperi & $4 / 1$ & $2 / 2$ & $3 / 2^{*}$ & $4 / 4$ & communis & Shoots \\
\hline C. (Cu.) cupressi & $0 / 0$ & $0 / 0$ & $1 / 1^{*}$ & $0 / 0$ & virginiana & Twigs \\
\hline C. (Cu.) mordvilkoi & $0 / 0$ & $0 / 0$ & $0 / 0$ & $3 / 3$ & communis & Branches, stem, root collar \\
\hline \multicolumn{7}{|c|}{ Thuja } \\
\hline C. (Cu.) cupressi & $1 / 1$ & $1 / 1$ & $2 / 2^{*}$ & $1 / 1$ & occidentalis & Twigs \\
\hline \multicolumn{7}{|c|}{ Larix } \\
\hline C. (C.) cuneomaculata & $1 / 1$ & $0 / 0$ & $1 / 1$ & $2 / 1$ & decidua (1), kaempferi (1), sp. (1) & Shoots, twigs \\
\hline C. (C.) kochiana & $0 / 0$ & $0 / 0$ & $0 / 0$ & $1 / 1$ & decidua & Branches, stem \\
\hline C. (C.) laricis & $1 / 1^{*}$ & $0 / 0$ & $0 / 0$ & $2 / 2$ & decidua (2), sp. (1) & Twigs, branches \\
\hline \multicolumn{7}{|c|}{ Picea } \\
\hline C. (C.) costata & $1 / 1$ & $1 / 1$ & $1 / 1$ & $0 / 0$ & abies & Twigs \\
\hline C. (C.) piceae & $6 / 4$ & $0 / 0$ & $2 / 2$ & $1 / 1$ & abies (7), omorika (1), alcoquiana (1) & Branches, stem \\
\hline C. (C.) piceicola & $1 / 1$ & $1 / 1$ & $3 / 1$ & $4 / 4$ & abies (8), montigena (1) & Shoots, twigs, branches, stem \\
\hline C. (C.) pilicornis & $1 / 1$ & $0 / 0$ & $5 / 2$ & $6 / 4$ & abies (11), montigena (1) & Shoots, twigs \\
\hline C. (C.) pruinosa & $2 / 2$ & $2 / 2$ & $3 / 1$ & $4 / 3$ & abies & Twigs, branches, stem \\
\hline \multicolumn{7}{|c|}{ Pinus } \\
\hline C. (C.) brauni & $5 / 2^{*}$ & $1 / 1$ & $3 / 3$ & $2 / 2$ & nigra (1), aff. nigra (10) & Shoots, twigs \\
\hline C. (C.) hyperophila & $3 / 3$ & $2 / 2$ & $6 / 2$ & $9 / 4$ & sylvestris (19), mugo (1) & Shoots, twigs \\
\hline C. (C.) neubergi & $4 / 2$ & $5 / 3$ & $7 / 2$ & $6 / 3$ & mugo & Shoots \\
\hline C. (C.) nuda & $3 / 2$ & $0 / 0$ & $2 / 2$ & $7 / 4$ & sylvestris & Shoots, twigs, branches, stem \\
\hline C. (C.) pilosa & $2 / 1$ & $0 / 0$ & $1 / 1$ & $8 / 5$ & sylvestris & Shoots \\
\hline C. (C.) pinea & $2 / 2$ & $2 / 2$ & $9 / 2$ & $10 / 3$ & sylvestris (19), mugo (4) & Shoots \\
\hline C. (C.) pini & $4 / 2$ & $1 / 1$ & $7 / 2$ & $12 / 5$ & sylvestris (23), mugo (1) & Shoots, twigs, branches, stem \\
\hline C. (C.) piniphila & $8 / 6$ & $2 / 2$ & $0 / 0$ & $4 / 4$ & sylvestris (11), mugo (3) & Shoots, twigs \\
\hline C. (S.) obscura & $4 / 4$ & $0 / 0$ & $1 / 1$ & $0 / 0$ & aff. nigra & Needles \\
\hline C. (S.) pineti & $2 / 1$ & $0 / 0$ & $5 / 2$ & $10 / 5$ & sylvestris (13), nigra (1), mugo (1) & Needles \\
\hline E. agilis & $1 / 1$ & $0 / 0$ & $3 / 1$ & $4 / 3^{*}$ & sylvestris (5), P. mugo (1) & Needles \\
\hline E. brevipilosus & $4 / 3$ & $0 / 0$ & $1 / 1$ & $1 / 1$ & sylvestris (7), P. mugo (1) & Needles \\
\hline E. nigricola & $1 / 1$ & $0 / 0$ & $0 / 0$ & $0 / 0$ & heldreichii & Needles \\
\hline E. rileyi & $2 / 2$ & $0 / 0$ & $1 / 1$ & $1 / 1$ & sylvestris (1), aff. nigra (2), sp. (1) & Needles \\
\hline
\end{tabular}




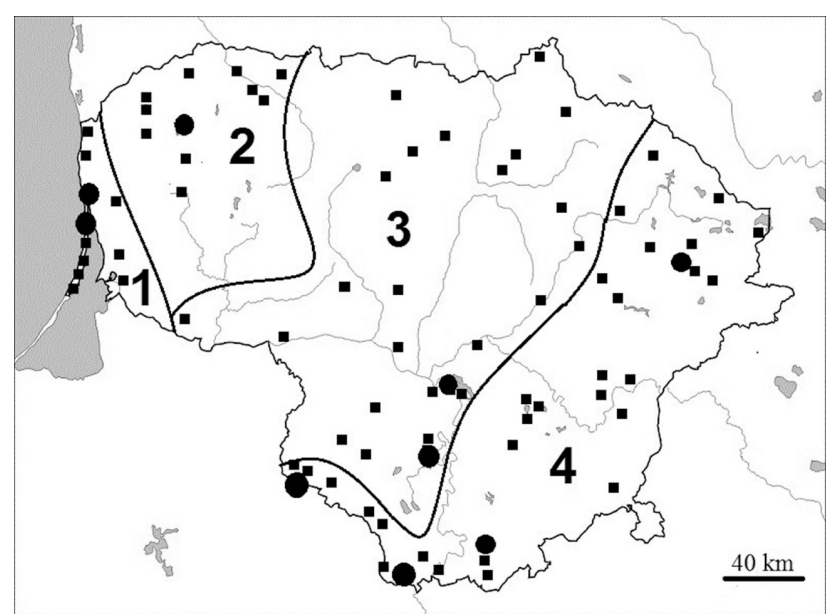

Fig. 1. Map showing the sites where aphids were collected in 2016-2018 in four Climatic regions in Lithuania. Localities also used for monitoring aphid colonies are shown as black circles. 1 - Coastal, 2 - Samogitian, 3 - Middle Lithuanian lowlands, 4 Southeastern highlands.

(1995), Binazzi \& Scheurer (2009), Albrecht (2017) and Kanturski et al. (2017) were used. NIKON ECLIPSE E200 microscope with INFINITY ANALYSE 6.1 software was used for the microscopic analysis. Aphid material is deposited in the Life Sciences Centre of Vilnius University (Lithuania).

For the molecular analysis, 161 samples of species of Eulachnini from many host plants and four climatic regions were used. A single aphid from a sample was considered to be a unique sample. A non-destructive extraction method was used so that each aphid could be mounted on a slide and used to confirm its identity when the morphological and DNA identification appeared to differ. Total genomic DNA was extracted from a single aphid using DNeasy Blood \& Tissue kit (Qiagen). For the amplification of COI fragments the primers LCO-1490 and HCO-2198 (Folmer et al., 1994) were used. For the amplification of EF-1 $\alpha$ fragments the primers Ef3 and Ef6 (Jousselin et al., 2013) were used. PCR amplification was carried out in a thermal cycler (Eppendorf) in $50 \mu \mathrm{l}$ volumes containing $2 \mu \mathrm{l}$ genomic DNA, $2.5 \mu \mathrm{l}$ of each primer $(0.5 \mu \mathrm{M}), 25 \mu \mathrm{l}$ of DreamTaq PCR master mix (Thermo Scientific) and $18 \mu \mathrm{l}$ of nuclease free water (Thermo Scientific). The cycling parameters were as follows: denaturizing at $95^{\circ} \mathrm{C}$ for $5 \mathrm{~min}(1 \mathrm{cycle})$, denaturizing at $95^{\circ} \mathrm{C}$ for $30 \mathrm{~s}$, annealing at $47^{\circ} \mathrm{C}(\mathrm{COI})$ or $50^{\circ} \mathrm{C}(\mathrm{EF}-1 \alpha)$ for $30 \mathrm{~s}$, extension at $72^{\circ} \mathrm{C}$ for $30-90 \mathrm{~s}\left(34\right.$ cycles in total) and final extension at $72^{\circ} \mathrm{C}$ for $5 \mathrm{~min}(1 \mathrm{cycle})$. PCR products were purified using Gene Jet PCR purification kit (Thermo Scientific) and then sequenced at Macrogen Europe (Amsterdam, the Netherlands) and the Institute of Biotechnology (Life Sciences Centre, Vilnius University). The amplification primers were also used as sequencing primers. DNA sequences for each specimen were confirmed using both sense and anti-sense strands and aligned in the BioEdit Sequence Alignment Editor (Hall, 1999). Partial COI sequences were tested for stop codons and none were found. The GenBank Accession numbers are MH396414-MH396434, MK829820-MK829825, MN178356-MN178483 and MN192192-MN192351.

To evaluate within-species sequence diversity uncorrected p-distances were calculated for the COI and EF- $1 \alpha$ fragments. Both exons and introns of EF- $1 \alpha$ were included in the analyses. Sequences were also collapsed into haplotypes using FaBox 1.5 (Villesen, 2007). Neighbour-Joining (NJ) trees for each of analysed fragments were constructed based on within- and between- species distance matrices. MEGA 7 (Kumar et al., 2016) was used for calculating the distances and tree construction.

We used three methods of molecular species delimitation: distance-based Automatic Barcode Gap Discovery (ABGD) (Puillandre et al., 2012), tree-based General Mixed Yule Coalescent (GMYC) (Pons et al., 2006) and the Poisson Tree Processes (PTP) models (Zhang et al., 2013). Partial COI sequences and coding part of EF-1 $\alpha$ fragment of Lithuanian samples were analysed using the graphic web version of the ABGD method (http:// wwwabi.snv.jussieu.fr/public/abgd/abgdweb.html). Distances for each gene were calculated using MEGA 7 (Kumar et al., 2016) and a Kimura 2-parameter (K2P) model. The value of the relative gap width $(\mathrm{X})$ was 1.00 for both fragments, with $\mathrm{P}_{\min }=0.001$ and $\mathrm{P}_{\max }=0.02$ for both fragments and other parameters by default. For tree-based methods, the following substitution models were used along with jmodeltest (Posada, 2008): HKY $+\mathrm{I}+\mathrm{G}$ for $\mathrm{COI}$ and $\mathrm{GTR}+\mathrm{G}$ for EF- $1 \alpha$ fragment. One ultra metric tree for each fragment was constructed using the uncorrelated lognormal relaxed clock method implemented in BEAST v1.7.4 (Drummond \& Rambaut, 2007), assuming a Yule tree prior. One run of 50 million generations with sampling every 5000 generations was performed. Convergence was checked for using Tracer 1.5 (Drummond \& Rambaut, 2007). Sampled posterior trees were summarized using TreeAnnotator 1.7.4 (Drummond \& Rambaut, 2007) to generate a maximum clade credibility (MCC) tree without the removal of burn-in. The GMYC method, as implemented in the R package SPLITS (http://www.rforge.r-project.org/projects/splits/) was then applied to the MCC tree and a lists of species derived from this phylogenetic tree. Contrary to GMYC, the PTP method does not require ultra metric trees as an input (Zhang et al., 2013). Bayesian inference trees for each fragment were built using MrBayes 3.2.1 (Ronquist \& Huelsenbeck, 2003). One run of 1,000,000 MCMC generations with tree sampling every 1,000 generations was performed. Consensus trees with posterior probabilities were visualized using TreeView (Page, 1996). Trees were saved as newick format files and analysed using the bPTP web server (http://species.h-its.org/ptp/). All parameters used were those given by default, except for the number of generations $(300,000)$.

\section{RESULTS}

\section{Distribution, host plants and life cycles of species of Eulachnini in Lithuania}

Our study revealed twenty-six aphid species of the tribe Eulachnini in Lithuania (Table 1). We failed to find Cinara (Cinara) pinihabitans (Mordvilko, 1895), which was previously reported from the Curonian spit of Lithuania (Rakauskas et al., 2008). Most of the species (17) are members of the subgenus Cinara of the genus Cinara. There are 3 species of the subgenus Cupressobium and 2 of the subgenus Schizolachnus. The four climatic regions in Lithuania differ in terms of the diversity of Eulachnini (Figs 2-3): The highest species diversity was recorded in the Coastal region (23 species), whereas only 10 species were recorded in the Samogitian region. Species of the subgenus Cinara were placed in six ecological groups, each of which was associated with a different host plant. Species complex inhabiting host plants of the genus Pinus was the most common and numerous ( 8 aphid species). Of these species, five were among the most common species of Eulachnini in all regions in Lithuania: C. (Cinara) brauni Börner, 1940, C. (Cinara) hyperophila (Koch, 1855), C. (Cinara) neuber- 


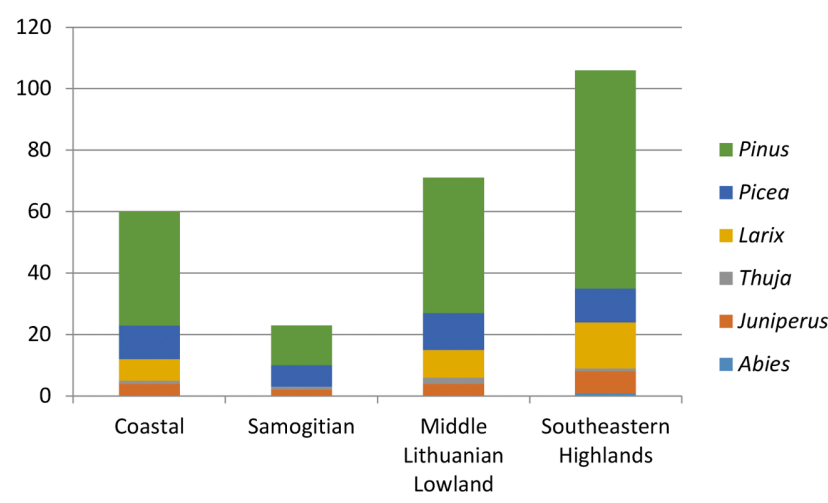

Fig. 2. Histogram of the numbers of aphid samples collected from different host plant genera in four climatic regions in Lithuania.

gi (Arnhart, 1930), C. (Cinara) pinea (Mordvilko, 1894) and $C$. (Cinara) pini (Linnaeus, 1758). Three of them $(C$. (Cinara) hyperophila, C. (Cinara) pinea and C. (Cinara) pini) mostly inhabited Pinus sylvestris Linnaeus 1753, which is the most common conifer in Lithuania. Two other widespread species of the subgenus Cinara, C. (Cinara) brauni and C. (Cinara) neubergi inhabited species of Pinus that are exotic to Lithuania: Pinus nigra J.F. Arnold 1785 group and $P$. mugo Turra 1765, respectively.

Six species of the subgenus Cinara coexist on native Pinus sylvestris. C. (Cinara) hyperophila usually feeds on shoots and twigs of mostly young pines and sometimes older trees. In autumn, it also inhabits needle-free parts of branches. Colonies are quite dense in spring, but become scattered later in the season. C. (Cinara) piniphila (Ratzeburg, 1844), C. (Cinara) pinea and C. (Cinara) pilosa (Zetterstedt, 1938) usually form small colonies or occur solitarily. C. (Cinara) piniphila occurred mostly on both fresh shoots and 1-2 year-old twigs throughout the entire season. Noticeably, we found this species on pines growing on poor sandy soil, mostly on dunes. C. (Cinara) pilosa and $C$. (Cinara) pinea occupy shoots and occasionally form mixed colonies on shoots of the lower branches of old trees. C. (Cinara) pilosa usually live on small shoots of old trees, but might also occur on mature (about 20 years old) pines. C. (Cinara) pinea occurs on both young and old trees. C. (Cinara) pini and C. (Cinara) nuda (Mordvilko, $1895)$ live in dense large colonies. $C$. (Cinara) pini commonly inhabits shoots and twigs both on young and old pines. Trunk and basal parts of old branches of immature trees are preferred by $C$. (Cinara) nuda. However, it can also be found on shoots and twigs in spring. Apart from P. sylvestris, we also found C. (Cinara) nuda on Pinus heldreichii Christ 1863 and C. (Cinara) hyperophila, C. (Cinara) pini, C. (Cinara) pinea and C. (Cinara) piniphila on $P$. mugo in Lithuania.

Five species of the subgenus Cinara inhabit Picea abies (Linnaeus) Karsten 1881, which is the second most common conifer in Lithuania. They coexist on the same host plant by utilizing specific microhabitats. The most common species were C. (Cinara) pruinosa (Hartig, 1841) and C. (Cinara) piceicola (Cholodkovsky, 1896). C. (Cinara) pruinosa occurred exclusively on Picea abies

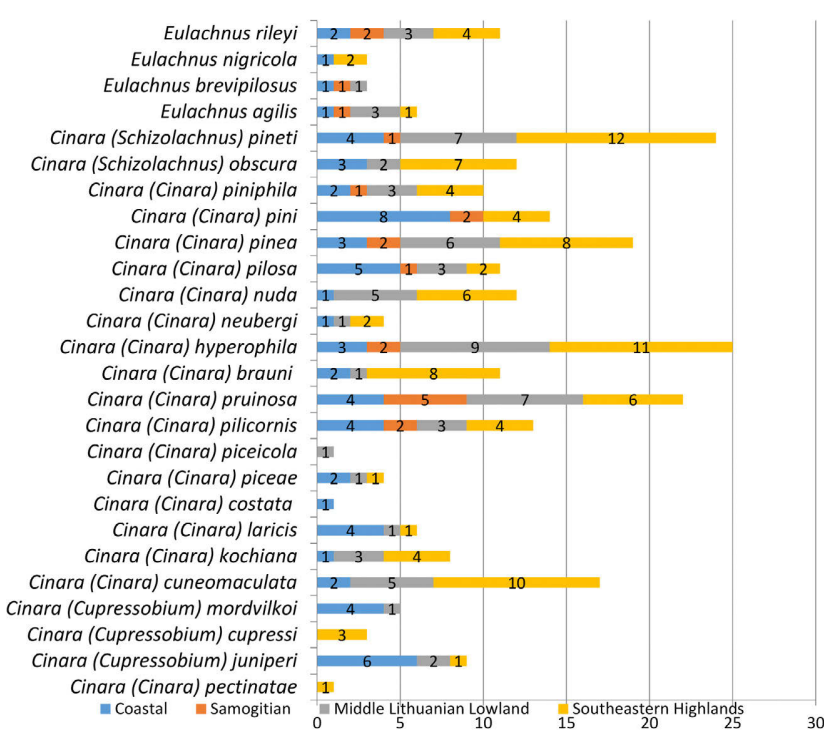

Fig. 3. Numbers of each of the species of aphids sampled in the four climatic regions in Lithuania.

where it formed dense and often large colonies on old twigs, branches and the upper parts of the trunk in spring and autumn. They did not occur in the canopies of trees from mid-July to mid-August, probably due to migration to lower parts of the trunk and big roots as is reported by Blackman \& Eastop (2019). C. (Cinara) piceicola inhabits twigs and young branches of Picea abies and sometimes the trunks and shoots. These two species sometimes form mixed colonies, although $C$. (Cinara) piceicola prefers the younger parts of trees. C. (Cinara) piceae (Panzer, 1800) was less common than the two above-mentioned species. The main reason is that this species may be overlooked due to its summer migration from branches and trunks to roots. These aphids were observed on trunks and branches of old and young trees in June-July and ovipositing oviparae on shoots and twigs in October. Apart from on Picea abies, C. (Cinara) piceae was also recorded on the exotic species Picea omorika (Pančić) Purkyne 1877 and P. alcoquiana (Veitch ex Lindley) Carrière 1867 in Lithuania. The rarest species of spruce-inhabiting aphid in Lithuania was C. (Cinara) costata (Zetterstedt, 1928) (Table 1), which lives in scarce colonies on small woody twigs on the lower branches in the crown and is covered in wax. The most common species on shoots and young twigs of Picea abies was $C$. (Cinara) pilicornis (Hartig, 1841).

Of the three species recorded on Larix in Lithuania, $C$. (Cinara) cuneomaculata (Del Guercio, 1909) was the most common. We recorded it living in small colonies on shoots and young woody twigs of Larix decidua Miller 1768, Larix kaempferi (Lambert) Carrière 1856 and on some unidentified species of larch in the Costal Lowland, Middle Lithuanian Lowland and South eastern Highland regions. Dense colonies of $C$. (Cinara) laricis (Hartig, 1839) were found on young and old trees of Larix decidua where they occurred on the shoots in spring and branches and trunk later in the season. It was recorded at sites in the Costal Lowland and South eastern Highland regions. C. (Cinara) kochiana (Börner, 1939) forms dense and large colonies 
on branches and trunk of young and old Larix decidua from midsummer until autumn. It was recorded only at one locality (Kapčiamiestis) in the southernmost part of the South eastern Highlands.

The only species of Eulachnini currently feeding on Abies in Lithuania is C. (Cinara) pectinatae (Nördlinger, 1880). The single finding of this aphid was recorded in the Kaunas botanical garden (Middle Lithuanian Lowland) on the exotic species Abies koreana E.H. Wilson 1920. Aphids were scattered individually on small branches among needles.

Three species of the subgenus Cupressobium of the genus Cinara are present in Lithuania, and C. (Cupressobium) juniperi (De Geer, 1773) is the most common. We found it in all climatic regions, where it formed small colonies on young shoots of the native conifer Juniperus communis Linnaeus 1753. Another species, C. (Cupressobium) mordvilkoi that inhabits the same host plant, was much rarer (three samples from the southernmost part of the South eastern Highlands, Table 1). These aphids feed on branches and stems in spring, root collar in summer and thin twigs at the end of September. A third species of the subgenus, C. (Cupressobium) cupressi (Buckton, 1881) was rather common feeding on shoots and small twigs of the exotic conifers Thuja occidentalis Linnaeus 1753 and Juniperus virginiana Linnaeus 1753 in Lithuania.

Of the two species of the subgenus Schizolachnus of the genus Cinara, the most common was $C$. (Schizolachnus) pineti (Fabricius, 1781). We found it in all climatic regions in Lithuania, except Samogitian, feeding in dense rows along the mature needles of mostly Pinus sylvestris. Some samples were also collected from $P$. mugo and $P$. nigra. Another species, C. (Schizolachnus) obscura (Börner, 1940), was much rarer and recorded mostly from $P$. nigra in the Coastal Lowland region, with one sample from the Middle Lithuanian Lowland region.

Of the four species of the genus Eulachnus the most common were E. agilis (Kaltenbach, 1843) and E. brevipilosus Börner, 1940, which were mostly associated with Pinus sylvestris and feed solitary on old needles. Some samples of both species were also collected from Pinus mugo. Our samples of E. rileyi (Williams, 1911) were mostly from Pinus nigra, but also P. mugo and P. sylvestris. We found this species in the Coastal Lowland, Middle Lithuanian Lowland and South eastern Highland regions, the same as the two above-mentioned species of Eulachnus. The only sample of Eulachnus nigricola (Pašek, 1953) was collected in the Coastal Lowland region (Botanical garden at Klaipeda) from the needles of $P$. heldreichii.

Table 2. Average and range of within-species genetic diversity (p-distances) calculated for COI (668 bp) and EF-1 $\alpha$ fragments (1017 bp) of 26 species of the tribe Eulachnini from Lithuania. C. - Cinara, Cu. - Cupressobium, S. - Schizolachnus, E. - Eulachnus.

\begin{tabular}{|c|c|c|c|c|}
\hline \multirow[t]{2}{*}{ Aphid species } & \multicolumn{2}{|c|}{ COI fragment } & \multicolumn{2}{|c|}{ EF-1alpha fragment } \\
\hline & $\begin{array}{c}\mathrm{p} \text {-distances, } \\
\text { average, } \min -\max \end{array}$ & $\begin{array}{l}\text { Haplotypes, n / } \\
\text { Samples, n }\end{array}$ & $\begin{array}{c}\mathrm{p} \text {-distances, } \\
\text { average, } \min -\max \end{array}$ & $\begin{array}{c}\text { Haplotypes, n / } \\
\text { Samples, n }\end{array}$ \\
\hline \multicolumn{5}{|c|}{ Abies } \\
\hline C. (C.) pectinatae & $\mathrm{n} / \mathrm{c}$ & $1 / 1$ & $\mathrm{n} / \mathrm{c}$ & $1 / 1$ \\
\hline \multicolumn{5}{|c|}{ Juniperus and Thuja } \\
\hline$\overline{C .}(\mathrm{Cu}$.$) juniperi$ & $1.21 ; 0.15-1.98$ & $8 / 8$ & $0.39 ; 0-0.76$ & $7 / 9$ \\
\hline C. (Cu.) mordvilkoi & 0 & $1 / 3$ & 0 & $1 / 3$ \\
\hline C. (Cu.) cupressi & 0 & $1 / 5$ & $0.41 ; 0-1.24$ & $3 / 6$ \\
\hline \multicolumn{5}{|c|}{ Larix } \\
\hline C. (C.) cuneomaculata & $1.26 ; 0.31-1.73$ & $3 / 3$ & 0 & $1 / 2$ \\
\hline C. (C.) kochiana & $n / c$ & $1 / 1$ & $n / c$ & $1 / 1$ \\
\hline C. (C.) laricis & $1.68 ; 0.63-2.36$ & $3 / 3$ & $0.10 ; 0-0.2$ & $3 / 3$ \\
\hline \multicolumn{5}{|c|}{ Picea } \\
\hline C. (C.) costata & $0.42 ; 0.31-0.63$ & $3 / 3$ & 0 & $1 / 3$ \\
\hline C. (C.) piceae & $0.17 ; 0-0.61$ & $3 / 7$ & $0.22 ; 0-0.65$ & $4 / 7$ \\
\hline C. (C.) piceicola & $0.20 ; 0-0.45$ & $4 / 7$ & $0.12 ; 0-0.32$ & $4 / 7$ \\
\hline C. (C.) pilicornis & $0.14 ; 0-0.32$ & $4 / 7$ & $0.58 ; 0.11-1.19$ & $7 / 7$ \\
\hline C. (C.) pruinosa & $0.08 ; 0-0.15$ & $3 / 8$ & $0.37 ; 0-0.64$ & $7 / 8$ \\
\hline \multicolumn{5}{|c|}{ Pinus } \\
\hline C. (C.) brauni & $0.17 ; 0-0.30$ & $5 / 7$ & $0.24 ; 0-0.96$ & $3 / 8$ \\
\hline C. (C.) hyperophila & $1.22 ; 0-3.92$ & $9 / 11$ & $0.15 ; 0-0.41$ & $4 / 10$ \\
\hline C. (C.) neubergi & $0.19 ; 0-0.94$ & $2 / 10$ & $0.23 ; 0-0.93$ & $4 / 10$ \\
\hline C. (C.) nuda & $0.17 ; 0-0.45$ & $4 / 7$ & $0.08 ; 0-0.22$ & $3 / 7$ \\
\hline C. (C.) pilosa & $0.04 ; 0-0.16$ & $2 / 7$ & $0.17 ; 0-0.31$ & $4 / 7$ \\
\hline C. (C.) pinea & $0.76 ; 0-1.25$ & $6 / 8$ & $0.42 ; 0-0.74$ & $4 / 9$ \\
\hline C. (C.) pini & $0.75 ; 0-1.67$ & $9 / 10$ & $0.09 ; 0-0.32$ & $4 / 10$ \\
\hline C. (C.) piniphila & $0.43 ; 0-1.41$ & $6 / 12$ & $0.27 ; 0-1.08$ & $6 / 13$ \\
\hline C. (S.) obscura & 0 & $1 / 4$ & $0.38 ; 0-0.86$ & $4 / 5$ \\
\hline C. (S.) pineti & $0.22 ; 0-0.49$ & $4 / 6$ & $0.03 ; 0-0.11$ & $2 / 8$ \\
\hline E. agilis & $0.18 ; 0-0.30$ & $4 / 5$ & $0.23 ; 0.11-0.32$ & $5 / 5$ \\
\hline E. brevipilosus & 0 & $1 / 5$ & 0 & $1 / 5$ \\
\hline E. nigricola & $n / c$ & $1 / 1$ & $n / c$ & $1 / 1$ \\
\hline E. rileyi & $0.15 ; 0-0.30$ & $3 / 4$ & $0.27 ; 0-0.54$ & $3 / 4$ \\
\hline
\end{tabular}




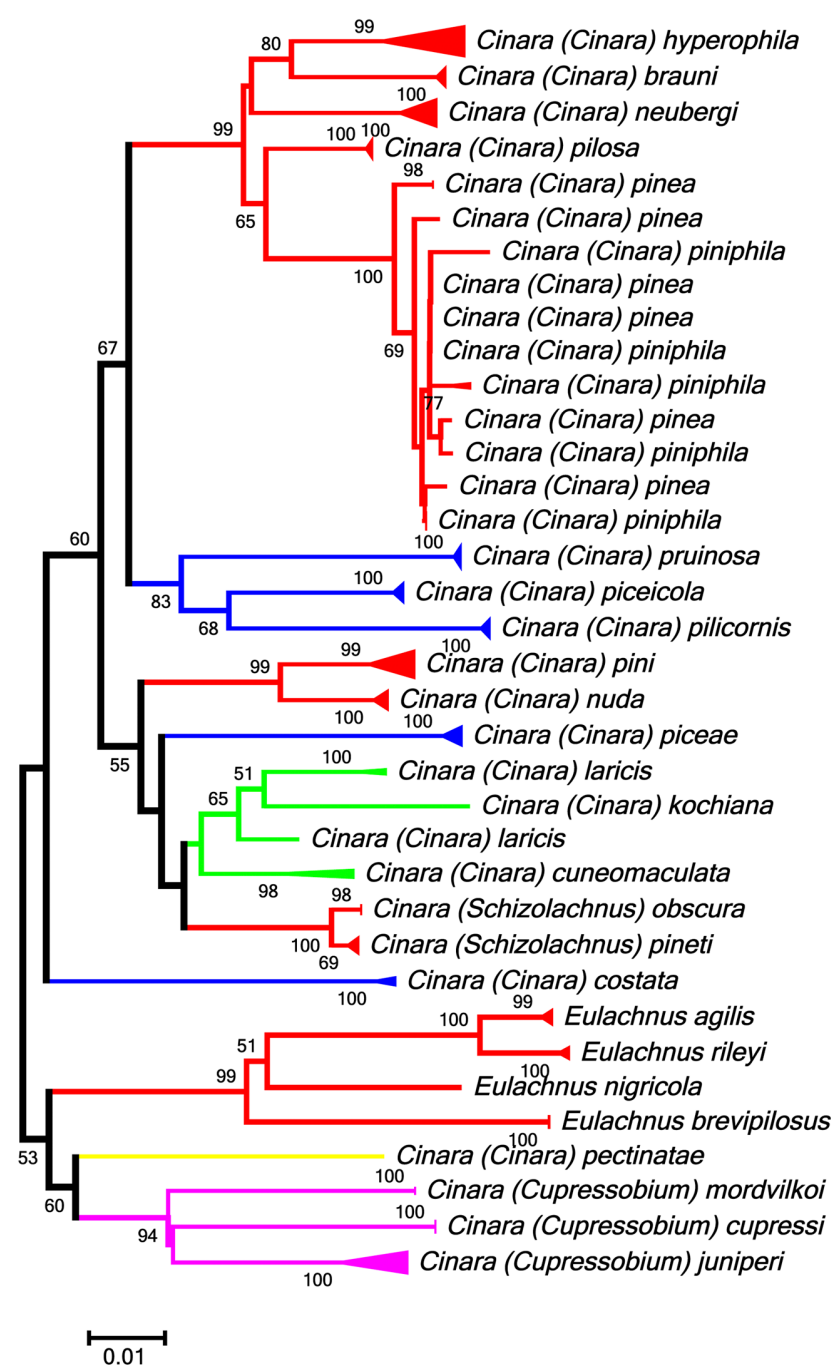

Fig. 4. Neighbour-joining (NJ) tree showing relationships among partial sequences of mitochondrial cytochrome oxidase subunit I (COI) in samples of 26 species of aphids of the tribe Eulachnini collected in Lithuania. - Pinus, - Abies, - - Larix, = - Picea, - - Cupressaceae. See Fig. S1 for details.

\section{Molecular diversity and taxonomy of species of Eulachnini in Lithuania}

Average and range of within-species genetic diversity (p-distances) based on COI (668 bp) and EF-1 $\alpha$ fragments (1017 bp) of 26 species of the tribe Eulachnini from Lithuania are given in Table 2. It is noteworthy, that this is the first record of the partial COI and EF-1 $\alpha$ sequences of $C$. (Cinara) hyperophila, C. (Cinara) pilosa and C. (Cinara) piceicola. The values of average intraspecific $\mathrm{p}$-distances for the COI fragment were higher than for EF-1 $\alpha$ fragment and ranged from $0 \%$ to $1.68 \%$ and $0 \%$ to $0.58 \%$, respectively. The number of haplotypes varied from 1 to 7 (for EF-1 $\alpha$ ) or 9 (for COI) (Table 2). Only one COI haplotype was detected in samples of $C$. (Schizolachnus) obscura. Identical EF-1 $\alpha$ sequences were recorded in samples of $C$. (Cinara) cuneomaculata and $C$. (Cinara) costata. Samples of $C$. (Cupressobium) mordvilkoi and E. brevipilosus were represented by a single haplotype of each fragment. The proportion of differences (p-distances) between our Eulachnini samples are represented by the NJ trees based

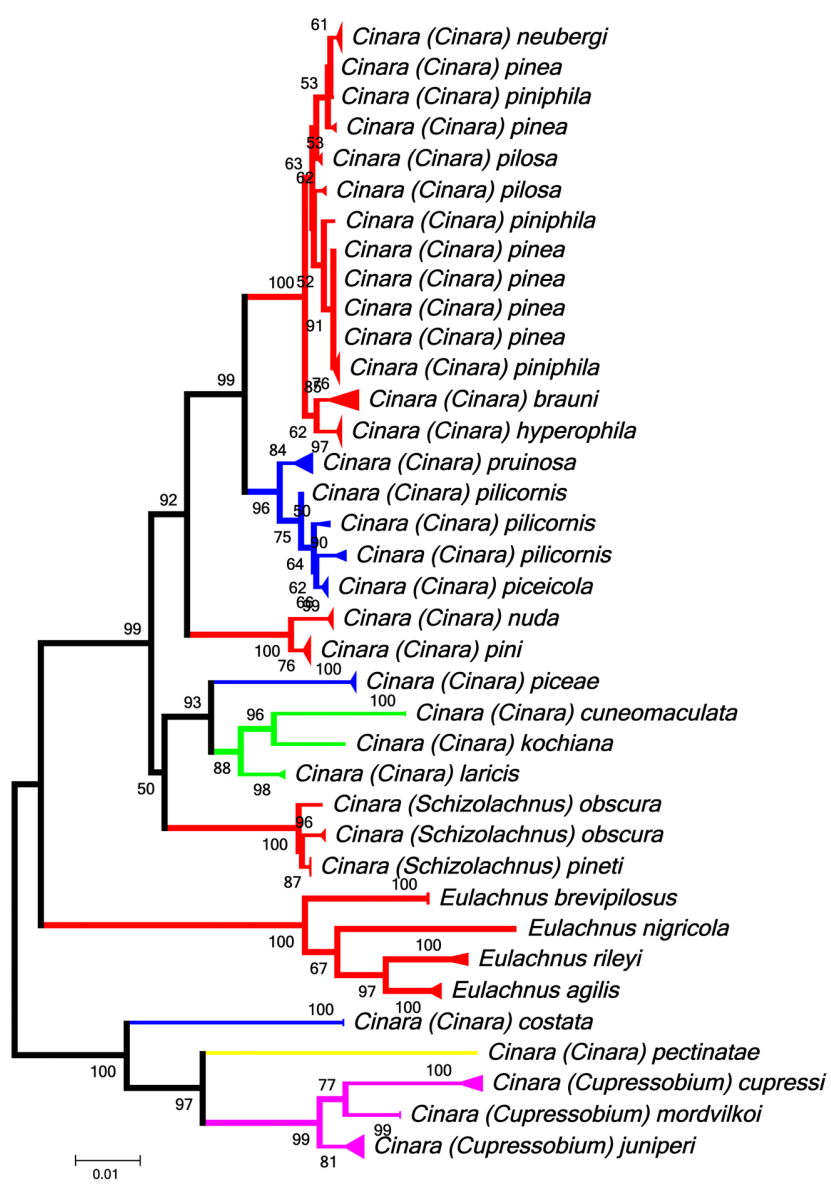

Fig. 5. Neighbour-joining (NJ) tree showing relationships among partial sequences of nuclear elongation factor 1 alpha $(E F-1 \alpha)$ in samples of 26 species of aphids of the tribe Eulachnini collected in Lithuania. - - Pinus, - - Abies, " - Larix, " - Picea, " - Cupressaceae. See Fig. S2 for details.

on both fragments (Figs 4-5). Average intrageneric pdistances were $4.73 \%(\mathrm{COI})$ and $2.58 \%(\mathrm{EF}-1 \alpha)$ for the genus Eulachnus, and 7.69\% (COI) and 5.48\% (EF-1 $\alpha)$ for the genus Cinara. Mean values of intergeneric p-distances were $11.71 \%$ for COI and $10.94 \%$ for EF-1 $\alpha$. Within each subgenus of the genus Cinara the average values of p-distances were: $7.00 \%(\mathrm{COI})$ and $3.62 \%(\mathrm{EF}-1 \alpha)$ for the subgenus Cinara, 4.64\% (COI) and 1.82\% (EF-1 $\alpha)$ for the subgenus Cupressobium and $0.51 \%$ (COI) and $0.34 \%$ (EF-1 $\alpha$ ) for the subgenus Schizolachnus. Mean values of p-distances were lowest between the subgenera Cinara and Schizolachnus and reached $7.40 \%$ for COI and $5.52 \%$ for EF-1 $\alpha$. Average p-distances between the subgenera Cinara and Cupressobium were $10.55 \%$ for COI and $10.95 \%$ for EF- $1 \alpha$. The values of mean p-distances between subgenera Cupressobium and Schizolachnus were $9.07 \%$ for COI and $11.43 \%$ for EF- $1 \alpha$.

Species delimitation based on COI and EF-1 $\alpha$ sequences gave different numbers of candidate species. The Automatic Barcode Gap Discovery (ABGD) method generated 24 and 19 candidate species based on partial COI sequences and the coding part of the EF-1 $\alpha$ fragment, respectively (Tables 3-4). General Mixed Yule Coalescent (GMYC) method resulted in 29 species based on COI fragment and 
Table 3. Species delimitation based on COI fragment data using Automatic Barcode Gap Discovery (ABGD), General Mixed Yule Coalescent (GMYC) and Poisson Tree Processes (PTP). Species names are those of the morphospecies identified. For more details, see Table S2. Species names, where molecular species delimitation definitely contradict the morphospecies status, are in bold.

\begin{tabular}{|c|c|c|c|c|}
\hline Morphospecies: 26 altogether & ABGD: 24 & GMYC: 29 & PTP BI: 34 & PTP ML: 32 \\
\hline $\mathrm{n}=$ number of sequences used & \multicolumn{4}{|c|}{$\mathrm{N}$ of candidate species: $\mathrm{n}$ of sequences per species } \\
\hline Cinara (Cinara) pectinatae $\mathrm{n}=1$ & 1 & 1 & 1 & 1 \\
\hline Cinara (Cupressobium) juniperi $\mathrm{n}=8$ & 1 & $2: 3+5$ & $3: 2+1+5$ & $3: 2+1+5$ \\
\hline Cinara (Cupressobium) mordvilkoi $\mathrm{n}=3$ & 1 & 1 & 1 & 1 \\
\hline Cinara (Cupressobium) cupressi $\mathrm{n}=5$ & 1 & 1 & 1 & 1 \\
\hline Cinara (Cinara) kochiana $\mathrm{n}=1$ & 1 & \multirow{3}{*}{$3: 3+1+3$} & 1 & 1 \\
\hline Cinara (Cinara) laricis $\mathrm{n}=3$ & \multirow{2}{*}{1} & & $2: 2+1$ & $2: 2+1$ \\
\hline Cinara (Cinara) cuneomaculata $\mathrm{n}=3$ & & & $2: 1+2$ & $2: 1+2$ \\
\hline Cinara (Cinara) costata $\mathrm{n}=3$ & 1 & 1 & $2: 1+2$ & 1 \\
\hline Cinara (Cinara) piceae $\mathrm{n}=7$ & 1 & 1 & 1 & 1 \\
\hline Cinara (Cinara) piceicola $\mathrm{n}=7$ & 1 & 1 & 1 & 1 \\
\hline Cinara (Cinara) pilicornis $\mathrm{n}=7$ & 1 & 1 & 1 & 1 \\
\hline Cinara (Cinara) pruinosa $\mathrm{n}=8$ & 1 & 1 & 1 & 1 \\
\hline Cinara (Cinara) brauni $\mathrm{n}=7$ & 1 & 1 & 1 & \\
\hline Cinara (Cinara) hyperophila $\mathrm{n}=11$ & $2: 10+1$ & $2: 9+2$ & $5: 7+1+1+1+1$ & $5: 7+1+1+1+1$ \\
\hline Cinara (Cinara) neubergi $\mathrm{n}=10$ & 1 & 1 & 1 & 1 \\
\hline Cinara (Cinara) nuda $\mathrm{n}=7$ & 1 & 1 & 1 & 1 \\
\hline Cinara (Cinara) pilosa $\mathrm{n}=7$ & 1 & 1 & 1 & 1 \\
\hline Cinara (Cinara) pinea $n=8$ & \multirow{2}{*}{1} & \multirow{2}{*}{$2: 4+8$} & \multirow{2}{*}{1} & \multirow{2}{*}{1} \\
\hline Cinara (Cinara) piniphila $\mathrm{n}=12$ & & & & \\
\hline Cinara (Cinara) pini $\mathrm{n}=10$ & 1 & $2: 6+4$ & 1 & 1 \\
\hline Cinara (Schizolachnus) obscura $\mathrm{n}=4$ & \multirow{2}{*}{1} & 1 & 1 & \multirow{2}{*}{1} \\
\hline Cinara (Schizolachnus) pineti $\mathrm{n}=6$ & & 1 & 1 & \\
\hline Eulachnus agilis $\mathrm{n}=5$ & 1 & 1 & 1 & 1 \\
\hline Eulachnus brevipilosus $\mathrm{n}=5$ & 1 & 1 & 1 & 1 \\
\hline Eulachnus nigricola $\mathrm{n}=1$ & 1 & 1 & 1 & 1 \\
\hline Eulachnus rileyi $\mathrm{n}=4$ & 1 & 1 & 1 & 1 \\
\hline
\end{tabular}

Table 4. Species delimitation based on EF-1a fragment data using Automatic Barcode Gap Discovery (ABGD), General Mixed Yule Coalescent (GMYC) model and Poisson Tree Processes (PTP). Species names are those of the morphospecies identified. For more details, see Table S3. Species names, where molecular species delimitation definitely contradict the morphospecies status, are in bold.

\begin{tabular}{|c|c|c|c|c|}
\hline Morphospecies: 26 altogether & ABGD: 19 & GMYC: 32 & PTP BI: 22 & PTP ML: 20 \\
\hline $\mathrm{n}=$ number of sequences used & \multicolumn{4}{|c|}{$\mathrm{N}$ of candidate species: $\mathrm{n}$ of sequences per species } \\
\hline Cinara (Cinara) pectinatae $\mathrm{n}=1$ & 1 & 1 & 1 & 1 \\
\hline Cinara (Cupressobium) juniperi $\mathrm{n}=9$ & $4: 2+5+1+1$ & $2: 4+4$ & 1 & 1 \\
\hline Cinara (Cupressobium) mordvilkoi $\mathrm{n}=3$ & 1 & 1 & 1 & 1 \\
\hline Cinara (Cupressobium) cupressi $\mathrm{n}=6$ & $2: 1+1+4$ & 1 & $2: 1+5$ & $2: 1+5$ \\
\hline Cinara (Cinara) kochiana $\mathrm{n}=1$ & 1 & 1 & 1 & 1 \\
\hline Cinara (Cinara) cuneomaculata $\mathrm{n}=2$ & 1 & 1 & 1 & 1 \\
\hline Cinara (Cinara) laricis $\mathrm{n}=3$ & 1 & 1 & 1 & 1 \\
\hline Cinara (Cinara) costata $\mathrm{n}=3$ & 1 & 1 & 1 & 1 \\
\hline Cinara (Cinara) piceae $\mathrm{n}=7$ & 1 & 1 & $2: 6+1$ & $2: 6+1$ \\
\hline Cinara (Cinara) piceicola $\mathrm{n}=7$ & \multirow{11}{*}{1} & 1 & \multirow{2}{*}{1} & \multirow{3}{*}{1} \\
\hline Cinara (Cinara) pilicornis $\mathrm{n}=7$ & & $2: 4+3$ & & \\
\hline Cinara (Cinara) pruinosa $\mathrm{n}=8$ & & $2: 3+5$ & 2: $7+1$ & \\
\hline Cinara (Cinara) brauni $\mathrm{n}=8$ & & 2: $7+1$ & \multirow{6}{*}{1} & \multirow{6}{*}{1} \\
\hline Cinara (Cinara) hyperophila $\mathrm{n}=10$ & & 1 & & \\
\hline Cinara (Cinara) neubergi $\mathrm{n}=10$ & & 1 & & \\
\hline Cinara (Cinara) pilosa $\mathrm{n}=7$ & & 2: $4+3$ & & \\
\hline Cinara (Cinara) pinea $\mathrm{n}=8$ & & $2: 5+15$ & & \\
\hline Cinara (Cinara) piniphila $\mathrm{n}=13$ & & 1 & & \\
\hline Cinara (Cinara) nuda $\mathrm{n}=7$ & & 1 & 1 & 1 \\
\hline Cinara (Cinara) pini $\mathrm{n}=10$ & & 1 & 1 & 1 \\
\hline Cinara (Schizolachnus) obscura $\mathrm{n}=5$ & 2: $1+4$ & 1 & 1 & \multirow{2}{*}{1} \\
\hline Cinara (Schizolachnus) pineti $\mathrm{n}=8$ & 1 & 1 & 1 & \\
\hline Eulachnus agilis $\mathrm{n}=5$ & \multirow{2}{*}{1} & 1 & 1 & 1 \\
\hline Eulachnus rileyi $\mathrm{n}=4$ & & 1 & 1 & 1 \\
\hline Eulachnus brevipilosus $\mathrm{n}=5$ & 1 & 1 & 1 & 1 \\
\hline Eulachnus nigricola $\mathrm{n}=1$ & 1 & 1 & 1 & 1 \\
\hline
\end{tabular}


32 species on partial EF-1 $\alpha$ sequences. Poisson Tree Processes (PTP) method generated 34 (BI) and 32 (ML) species for COI and 22 (BI) and 20 (ML) species for the EF-1 $\alpha$ fragment. The best match with number of morphospecies (26 species) was from COI-based ABGD procedures (24 species). EF-1 $\alpha$ fragment based species delimitation resulted in the highest mismatch with number of morphospecies: 19 candidate species in ABGD, 20(ML)/22 (BI) in PTP and 32 in GMYC. The three COI and EF-1 $\alpha$ sequences for C. (Cupressobium) mordvilkoi were grouped as one candidate species by all delimitation methods. The same result emerged for Eulachnus brevipilosus. At least five out of eight delimitation analyses (COI and EF-1 $\alpha$ data and four delimitation methods) coincided with the morphospecies C. (Cupressobium) cupressi, C. (Cinara) costata, C. (Cinara) piceae, C. (Cinara) piceicola, C. (Cinara) neubergi, C. (Cinara) nuda, C. (Cinara) pini, Eulachnus agilis, E. nigricola and E. rileyi. C. (Cupressobium) juniperi was identified as a complex of genospecies by five out of eight delimitation analyses. Sequences of the $C$. (Cinara) pinea and $C$. (Cinara) piniphila morphospecies were grouped as one genospecies by six out of eight delimitation analyses. Cinara (Cinara) hyperophila was grouped with several other species based on EF-1 $\alpha$ data, but was separated from them when based on COI fragment analyses (Tables 3-4).

Based on the morphological, ecological and molecular data, four distinct groups of species of Eulachnini inhabit pines (Pinus spp.) in Lithuania: four species of the genus Eulachnus, two species of the subgenus Schizolachnus and two distinct groups of the subgenus Cinara. $C$. (Cinara) piniphila, C. (Cinara) pinea, C. (Cinara) pilosa, C. (Cinara) neubergi, C. (Cinara) brauni and C. (Cinara) hyperophila, are broad egg-shaped aphids, which mostly live sparsely on fresh shoots and 1-2 year-old twigs of $P$. sylvestris. Two other species, $C$. (Cinara) nuda and $C$. (Cinara) pini, are narrow and elongate, and usually form dense large colonies on stems and branches of $P$. sylvestris. They also appear separate on NJ trees (Figs 4-5). Three groups of Cinara species inhabit spruce (Picea spp.) in Lithuania. One group consists of three well-defined species, C. (Cinara) piceicola, C. (Cinara) pilicornis and $C$. (Cinara) pruinosa, which are common throughout Lithuania (Table 1). Remaining two clades of spruce inhabiting Cinara species are based on the sequences of two species (Figs 4-5). Sequences of C. (Cinara) piceae appeared to be closer to the larch (Larix spp.) dwelling Cinara species,
C. (Cinara) laricis, C. (Cinara) kochiana and C. (Cinara) cuneomaculata, and Pinus inhabiting species of the subgenus Schizolachnus. Sequences of $C$. (Cinara) costata were closer to fir (Abies spp.) inhabiting C. (Cinara) pectinatae and species of the subgenus Cupressobium.

\section{DISCUSSION AND CONCLUSIONS}

The values of average intraspecific and interspecific pdistances for COI and EF-1 $\alpha$ fragments recorded in this study coincide with previously published data (Kim \& Lee, 2008; Bašilova \& Rakauskas, 2012; Coeur d'Acier et al., 2014; Rakauskas et al., 2014; Chen et al., 2016a; Arnal et al., 2019). Consequently, the NJ trees based on partial sequences of both fragments coincide rather well with the morphospecies (Figs 4-5), as does the grouping of the COI sequences using Automatic Barcode Gap Discovery (ABGD) and General Mixed Yule Coalescent (GMYC) methods (Table 3 ). These analyses reveal the taxonomic similarity of $C$. (Cinara) piniphila and C. (Cinara) pinea. Their average between-species sequence divergences were $0.73 \%(0-1.88 \%)$ for COI and $0.44 \%(0-1.19 \%)$ for EF$1 \alpha$, which is the lowest among the species pairs analysed in this study. Sequences of both species were intermixed forming a mutual clade on both NJ trees, despite the presence of introns in the partial sequences of EF-1 $\alpha$ (Figs 4-5). Samples of $C$. (Cinara) pinea and C. (Cinara) piniphila were also intermixed or merged into one group by the PTP, GMYC and ABGD analyses (Tables 3-4). Such discrepancies between morphospecies and genospecies strongly supports the synonymy of both species and coincides with reference data (Chen et al., 2012; 2016b; Arnal et al., 2019). Actually, minor differences and overlapping values of some characters are presented in the identification keys for both species as well as the data on their morphology and feeding site, see Table 5. In addition, our data reveal that the number of hairs on antennal segment II is 10-13 for C. (Cinara) piniphila compared with 5-10 for C. (Cinara) pinea. Maximum length of the hair on the fifth abdominal tergite in our material was $108-191 \mu \mathrm{m}$ for $C$. (Cinara) pinea and 26-70 $\mu \mathrm{m}$ for C. (Cinara) piniphila. Reference data also indicate subtle differences in the host plant preference of both species. C. (Cinara) piniphila prefers young pines growing in costal dunes attended by Formica cinerea, whilst $C$. (Cinara) pinea prefers open habitats: forest margins, clearings, rocks and dry meadows (Albrecht, 2017). The samples collected and monitoring data also

Table 5. Characters used in this study to discriminate between the apterous viviparous females of $C$. (Cinara) pinea and $C$. (Cinara) piniphila (after Blackman \& Eastop, 2019 and Albrecht, 2017).

\begin{tabular}{|c|c|c|}
\hline Character & C. (Cinara) pinea & C. (Cinara) piniphila \\
\hline $\begin{array}{l}\text { Longest hair on the fifth } \\
\text { abdominal tergite }\end{array}$ & $\begin{array}{l}60-230 \mu \mathrm{m} \text { long, those on the largest scleroites } \\
\text { usually exceed the diameter of a scleroite }\end{array}$ & $\begin{array}{l}70-80 \mu \mathrm{m} \text {, those on the largest scleroites do not } \\
\text { or hardly exceed the diameter of these scleroites }\end{array}$ \\
\hline Hairs on abdominal dorsum & Longer than $0.1 \mathrm{~mm}$ & Not longer than $0.1 \mathrm{~mm}$ \\
\hline Hairs on legs & $\begin{array}{l}\text { More or less upright, on tibiae equal } \\
\quad \text { or longer than width of tibia }\end{array}$ & $\begin{array}{l}\text { Oblique, on tibiae about half } \\
\text { as long as width of tibia }\end{array}$ \\
\hline Longest hairs on hind tibiae & $70-230 \mu \mathrm{m}$ & $60-90 \mu \mathrm{m}$ \\
\hline No of hairs on antennal segment II & $5-10$ & Not specified \\
\hline Feeding site & $\begin{array}{l}\text { Young shoots, terminal twigs, cone } \\
\text { and flower bases. New shoots. }\end{array}$ & $\begin{array}{l}\text { Young shoots and 1-2 year-old twigs. } \\
\text { Bark of 1- or 2-year-old twigs, among needles. }\end{array}$ \\
\hline
\end{tabular}


indicates $C$. (Cinara) piniphila inhabits young pines $(P$. sylvestris, $P$. mugo) in costal and continental dunes, attended by Formica cinerea, whilst $C$. (Cinara) pinea inhabits the same species of pine, but older trees growing on more fertile soils, attended by other species of ants. Therefore, more data are needed, including a morphological analysis of all morphs based on clonal material originating from hypothesized species-specific environmental conditions: 1-2 years-old twigs of young pines growing on poor sandy soil (C. (Cinara) piniphila) versus shoots of mature plants $(C$. (Cinara) pinea). In particular, the morphological analysis of male genitalia might be of great importance in the case of Lachninae aphids due to previously unknown valuable peculiarities (Wieczorek et al., 2012).

Based on the samples from Lithuania, C. (Schizolachnus) obscura and $C$. (Schizolachnus) pineti seem to be problematic taxa. Both species formed separate well-supported clades on the NJ trees (Fig. 4), yet values of betweenspecies p-distances between samples were low (average $0.81 \%$, range $0.65-0.98 \%$ for COI; average $0.55 \%$, range $0.43-0.75 \%$ for EF-1 $\alpha$ ). Morphological identification of the samples (based on Albrecht, 2017; Blackman \& Eastop, 2019) coincide with the species delimitation results of GMYC (COI and EF-1 $\alpha$ ), PTP BI (COI) and ABGD (EF$1 \alpha$ ) methods, but were mismatched by the others (Tables 3-4). Our data confirm the differences in host specificity of both species already reported by Albrecht (2017) and Blackman \& Eastop (2019). Most of our samples of $C$. (Schizolachnus) pineti were from Pinus sylvestris, whereas those of $C$. (Schizolachnus) obscura were from the $P$. nigra group. Therefore, the taxonomic status of these species awaits a proper analysis as was recently suggested by Kaszyca-Taszakowska et al. (2019).

From the ecological viewpoint, pine-dwelling species of the subgenus Cinara co-exist in Lithuania by exploiting different species of pine or different microhabitats on the same host plant. This is reflected in our NJ trees based on COI and EF-1 $\alpha$ fragments (Figs 4-5) and coincides with the Bayesian tree based on six gene fragments, including both aphid (COI, Cytb, Aph and EF-1 $\alpha$ ) and Buchnera aphidicola (GroEL and His) DNA sequences (Jousselin et al., 2013; Meseguer et al., 2015). The evidence that speciation of the Eulachnini was mostly host plant mediated is very strong. Nevertheless, one should not ignore the possible role of climatic niche, landscape history and geographic barriers (Jousselin et al., 2013; Meseguer et al., 2015; Arnal et al., 2019).

Our data provide information relevant to the discussion on the reliability of molecular markers and molecular species delimitation (Chen et al., 2012, 2016a, b; Jousselin et al., 2013; Arnal et al., 2019). Namely, our data indicate that most species are distinct in their ecological and morphological characteristics. Accepting that the "traditional" species delimitation is correct, the most reliable molecular species delimitation was that based on the Automatic Barcode Gap Discovery (ABGD) method and COI sequence data set. It correctly delimited 24 of the 26 morphospecies used in the present study (Table 3 ). It also confirmed the taxonomic uncertainty of the above-mentioned C. (Cinara) piniphila $-C$. (Cinara) pinea species complex. In addition, it confirmed that $C$. (Schizolachnus) obscura and $C$. (Schizolachnus) pineti are closely related taxa (see above for more details). In summary, it correctly identified all the material sampled. COI partial sequences were reliable also in combination with the General Mixed Yule Coalescent (GMYC) model (29 genospecies and 26 morphospecies, Table 3). In contrast, molecular species delimitation using EF-1 $\alpha$ fragment analysis was least compatible with traditional taxonomy of all the methods used in this study (Table 4). Noticeably, the PTP method was most reliable when used with the EF-1 $\alpha$ data matrix: it generated 20 (BI) and 21 (ML) candidate species against 26 morphospecies. In the case of the COI data it was 32 (ML) and 34 (BI) against 26 (Tables 3-4). In conclusion, niche analysis was the best way to delimit species. Morphological, molecular and other information is important, however, when diagnosing species already delimited on ecological grounds.

Currently the Lithuanian fauna of Eulachnini is rather poor compared with that of the southernmost Central European floristic province (27 species against 40 species in the Czech Republic, Slovakia and Austria). This is due to the poorer biodiversity of coniferous plants with only four conifers listed in the native flora of Lithuania: Pinus sylvestris, Picea abies, Juniperus communis and Taxus baccata Linnaeus 1753, the latter of which is a rare relict species (Ozolinčius et al., 2003). Currently, sixteen species of Eulachnini occur exclusively on native species of conifers in Lithuania (6 species) or mostly on native conifers (10 species, Table 1). Nine species of Eulachnini were recorded only on exotic species of conifers in Lithuania. Of the four samples of Eulachnus rileyi, three were collected from exotic species of pine and one from native $P$. sylvestris. Nevertheless, succession in plant communities due to global warming and increasing introductions of exotic plants (both natural and anthropogenic) might shortly enrich the Lithuanian fauna of Eulachnini. One of the possible exotic Lithuania newcomers is $C$. (Cinara) curvipes (Patch, 1912), a non-native species of Eulachnini of North American origin. The typical host plants of this species are Abies balsamea (Linnaeus) Miller 1768, A. concolor (Gordon \& Glendinning) Lindley ex Hildebrand 1861, $A$. grandis (Douglas ex D. Don) Lindley 1833, A. lasiocarpa (Hooker) Nuttall 1849, Picea engelmannii Parry ex Engelmann 1863 and P. glauca, which are already in Lithuania. In addition, some native and exotic species of conifers in Europe, such as Abies alba Miller 1759, A. koreana, A. nordmanniana (Steven) Spach 1841 and $A$. veitchii Lindley 1861, are reported to be suitable for this aphid, and are also present in Lithuania. Finally, C. (Cinara) curvipes has already colonized most countries in the Central European floristic province south of Lithuania, including central Poland (Halaj \& Osiadacz, 2015). The same is the case for C. (Cupressobium) tujafilina (Del Guercio, 1909), which is already in Poland and is reported producing sexual morphs important for spreading northwards. In addition, this spe- 
cies can overwinter on roots anholocyclically (Durak \& Durak, 2015).

Boreomontaneous species of Eulachnini currently in mountainous regions in the southernmost territories of the Central European floristic province, are expected to spread into Lithuania. For example, $C$. (Cinara) neubergi, which occurs in mountainous regions in Europe (Blackman \& Eastop, 2019) colonized Lithuania in 2017 (Danilov et al., 2019). Other possible candidates are the montaneous species C. (Cinara) montanicola Börner, 1939, C. (Cinara) carnica Binazzi, 1995 and C. (Cinara) covassii Binazzi, 1991 living on Pinus mugo, a species of conifer already in Lithuania and C. (Cinara) cembrae (Seitner, 1936), a boreomontaneous species living on Pinus cembra Linnaeus, 1753 in mountainous regions of Europe and in the St. Petersburg district of Russia (Blackman \& Eastop, 2019). Some species of Eulachnini are expected to colonize Lithuania from the north. A good example is C. (Cupressobium) smolandiae Danielsson \& Carter, 1993, which lives on Juniperus communis in Sweden (Danielsson \& Carter, 1993) and is reported in Finland (Albrecht, 2017) and the Scottish Highlands (Baker \& Blackman, 2014). In conclusion, seven additional species of the tribe Eulachnini are likely to shortly colonize both native and exotic coniferous plants in Lithuania.

ACKNOWLEDGEMENTS. This research was funded by grant No P-MIP-17-365 from the Research Council of Lithuania. Directors of the Dubrava Arboretum, Botanical gardens of Vilnius University, Vytautas Magnus University, Klaipedda University and Šiauliai University kindly allowed us to collect samples of aphids from their dendrological collections. D. Andriulioniene and L. \& A. Pivorai kindly helped with the field research of J. Danilov in western and north-eastern Lithuania, respectively. Authors gratefully acknowledge the important methodological help of Jan Havelka (Biology Centre of the Academy of Sciences of the Czech Republic, České Budějovice). He also provided some samples (asterisked in Table 1) he collected in Lithuania under the auspices of the Czech Academy of Sciences/Lithuanian Academy of Sciences exchange program. Our cordial thanks also go to three anonymous reviewers for their critical comments which improved the earlier version of manuscript.

\section{REFERENCES}

Albrecht A.C. 2017: Illustrated identification guide to the Nordic aphids feeding on Conifers (Pinophyta) (Insecta, Hemiptera, Sternorhyncha, Aphidomorpha). - Eur. J. Taxon. 338: 1-160.

Arnal P., Coeur d’acier A., Favret C., Godefroid M., Qiao G. X., Jousselin E. \& Meseguer A.S. 2019: The evolution of climate tolerance in conifer-feeding aphids in relation to their host's climatic niche. - Ecol. Evol. 9: 11657-11671.

BaKer E.A. \& Blackman R.L. 2014: Cinara (Cupressobium) smolandiae (Aphidoidea: Aphididae), a juniper-feeding aphid new to Britain. - Brit. J. Entomol. Nat. Hist. 27: 1-6.

BašILOVa J. \& RaKausKas R. 2012: Phylogenetic relationships of Dysaphis pyri (Boyer de Fonscolombe) and Dysaphis reaumuri (Mordvilko) (Hemiptera, Sternorrhyncha: Aphididae): COI and EF-1 $\alpha$ evidence. - Org. Divers. Evol. 12: 197-204.

Binazzi A. \& Scheurer S. 2009: Atlas of the Honeydew Producing Conifer Aphids of Europe. ARACNE, Roma, 127 pp.
Blackman R.L. \& EASTOP V.F. 2000: Aphids on the World's Crops. An Identification and Information Guide. John Wiley \& Sons, Chichester, 466 pp.

Blackman R.L. \& EAStOP V.F. 2019: Aphids on the World's Plants: An Identification and Information Guide. URL: http:// www.aphidsonworldsplants.info.

Buivydaitè V.V., VaičYs M., Juodis J. \& Motuzas A. 2001: Classification of Lithuanian Soils. Science in Lithuania, Vilnius, 139 pp. [in Lithuanian].

Chen R., Jiang L. \& Qiao G.X. 2012: The effectiveness of three regions in mitochondrial genome for aphid DNA barcoding: A case in Lachninae. - PLoS ONE 7(10): e46190, 11 pp.

Chen R., Favret C., Jiang L.Y., Chen R. \& Qiao G.X. 2016a: DNA barcoding reveals a mysterious high species diversity of coniferfeeding aphids in the mountains of southwest China. Sci. Rep. 6: 20123, 11 pp.

Chen R., Favret C., Jiang L.Y., Wang Z. \& Qiao G.X. 2016b: An aphid lineage maintains a bark-feeding niche while switching to and diversifying on conifers. - Cladistics 32: 555-572.

Coeur d'acier A., Cruaud A., Artige E., Genson G., Clamens A.L., Pierre E., Hudaverdian S., Simon J.C., Jousselin E. \& Rasplus J.Y. 2014: DNA barcoding and the associated Phy1AphidB@se website for the identification of European aphids (Insecta: Hemiptera: Aphididae). — PLoS ONE 9(6): e97620, $16 \mathrm{pp}$.

Danielsson R. \& CARTER C. 1993: Cinara smolandiae sp. n. from Juniperus communis in Sweden and a key to the species in the subgenus Cupressobium Börner (Homoptera: Aphidoidea: Lachnidae). - Entomol. Scand. 23: 475-479.

Danilov J., Havelka J. \& Rakauskas R. 2019: New for Lithuania aphid species of the tribe Eulachnini (Hemiptera: Aphididae, Lachninae): any threat to local coniferous forests? - Baltic For. 25: 25-31.

Dara S.K., Montalva C. \& Barta M. 2019: Microbial control of invasive forest pests with entomopathogenic fungi: A review of the current situation. - Insects 10: 341, $17 \mathrm{pp}$.

Drummond A.J. \& Rambaut A. 2007: BEAST: bayesian evolutionary analysis by sampling trees. - BMC Evol. Biol. 7: 214, $8 \mathrm{pp}$.

DURAK R. 2011: Molecular and morphological identification of Cinara juniperi and Cinara mordvilkoi. - Bul. Insectol. 64: 195-199.

DuRAK R. 2014: Life cycle, seasonal and interannual polymorphism in a monoecious aphid Cinara mordvilkoi (Hemiptera: Aphidoidea: Lachnidae). — Eur. J. Entomol. 111: 357-362.

DuraK R. \& DuRAK T. 2015: Redescription of males of the aphid species Cinara (Cupressobium) tujafilina and Cinara (Cupressobium) cupressi (Hemiptera, Lachninae). - Zootaxa 4032: 209-214.

Durak R., Lachowska-Cierlik D. \& Bartoszewski S. 2014: Relationships within aphids Cinara (Cupressobium) (Hemiptera) based on mitochondrial and nuclear DNA sequences. $-J$. Appl. Genet. 55: 89-96.

EASTOP V.F. 1972: A taxonomic review of the species of Cinara Curtis occurring in Britain (Hemiptera: Aphididae). - Bull. Brit. Mus. Nat. Hist. (Entomol.). 27: 104-186.

Folmer O., Black M., Hoeh W., Lutz R. \& Vrijehoek R. 1994: DNA primers for amplification of mitochondrial cytochrome C oxidase subunit I from diverse metazoan invertebrates. - Mol. Marine Biol. Biotechnol. 3: 294-299.

FREY W. \& Lösch R. 2010: Geobotanik: Pflanzen und Vegetation in Raum und Zeit, 3 ed. Spektrum, Heidelberg, 600 pp.

Galvonaitė A., Misiūnienè M., Valiukas D. \& Buttkuvienė M.S. 2007: Climate of Lithuania. Hydrometeorological Service of Lithuania, Vilnius, 180 pp. [in Lithuanian]. 
Galvonaitė A., Kitrienė Z. \& Valiukas D. 2013: Climate Averages for Lithuania. Hydrometeorological Service of Lithuania, Vilnius, $24 \mathrm{pp}$.

Halaj R. \& Osiadacz B. 2015: On foreign land: the conquest of Europe by Cinara curvipes (Patch, 1912). - Dt. Entomol. Z. 62: $261-265$.

HaLL T.A. 1999: BioEdit: a user-friendly biological sequence alignment editor and analysis program for Windows 95/98/NT. — Nucl. Acids Symp. 41: 95-98.

HeIE O.E. 1995: The Aphidoidea of Fennoscandia and Denmark VI. Aphidinae. Part 3 of Macrosiphini and Lachnidae. Fauna Entomol. Scand. 31: 222 pp.

Holman J. 2009: Host Plant Catalog of Aphids: Palaearctic Region. Springer, Dordrecht, $1216 \mathrm{pp}$.

Holman J. \& Pintera A. 1977: Aphidodea. - Acta Faun. Entomol. Mus. Nat. Prag. 4: 101-116.

Hopmans P. \& Elms S.R. 2013: Impact of defoliation by Essigella californica on the growth of mature Pinus radiata and response to N, P and S fertilizer. - For. Ecol. Manag. 289: 190-200.

Jousselin E., Cruaud A., Genson G., Chevenet F. \& Foottit, R.G. 2013: Is ecological speciation a major trend in aphids? Insights from a molecular phylogeny of the conifer-feeding genus Cinara. - Front. Zool. 10: 56, 18 pp.

KantURSKi M., Kajtoch L. \& WiecZoreK K. 2017: European species of the aphid genus Eulachnus Del Guercio, 1909 (Hemiptera: Aphididae: Lachninae): revision and molecular phylogeny. - Zootaxa 4356: 1-81.

Kaszyca-Taszakowska M., Senol O., Bugaj-Nawrocka A., Morawski M., Wyglenda A., Ledwon P., Maslowski A. \& Depa L. 2019: Species identity of Cinara (Schizolachnus) obscurus. In Durak R. (ed.): Aphids and Other Hemipterous Insects. Materials of the Twenty-Sixths Conference of the Hemiptera Section of the Polish Entomological Society, Berezka, Poland, September 17-20, 2019. Prodruk, Poznan, pp. 14-15.

KIM H. \& LeE S. 2008: Molecular systematics of the genus Megoura (Hemiptera: Aphididae) using mitochondrial and nuclear DNA sequences. - Mol. Cells 25: 510-522.

Kumar S., Stecher G. \& Tamura K. 2016: MEGA7: Molecular Evolutionary Genetics Analysis version 7.0 for bigger datasets. - Mol. Biol. Evol. 33: 1870-1874.

Meseguer A., Coeur D’acier A., Genson G. \& Jousselin E. 2015: Unravelling the historical biogeography and diversification dynamics of a highly diverse conifer-feeding aphid genus $-J$. Biogeogr. 42: 1482-1492.

Meseguer A., Manzano-Marin A., Coeur d'acier A., Clamens A.-L., Godefroid M. \& Jousselin E. 2017: Buchnera has changed flatmate but the repeated replacement of co-obligate symbionts is not associated with the ecological expansions of their aphid hosts. - Mol. Ecol. 26: 2363-2378.

Meusel H. \& JÄGER E.J. 1992: Vergleichende Chorologie der Zentraleuropäischen Flora III. Gustav Fischer, Jena. 333+688 pp.

Nieto Nafría J.M., Andreev A.V., Binazzi A., Mier Durante M.P., Pérez Hidalgo N., Rakauskas R. \& Stekolshchikov A.V. 2013: Aphidoidea. Fauna Europaea, Ver. 2.6.2. URL: https:// fauna-eu.org.

Osiadacz B. \& Halaj R. 2009: The aphids (Hemiptera: Sternorrhyncha: Aphidinea) of Poland. A distributional checklist. Pol. Entomol. Monogr. 6: 1-96.
Ozolinčius R., Navasaitis M., Balevičienė J. \& Smaliukas D. 2003: Dendroflora of Lithuania. Lutute, Kaunas, 576 pp. [in Lithuanian]

PAGE R.D.M. 1996: TREEVIEW: An application to display phylogenetic trees on personal computers. - Comp. Appl. Biosci. 12: 357-358.

Pons J., Barraclough T.G., Gomez-Zurita J., Cardoso A., Duran D.P., Hazell S., Kamoun S., Sumlin W.D. \& Vogler A.P. 2006: Sequence based species delimitation for the DNA taxonomy of undescribed insects. - Syst. Biol. 55: 595-609.

Posada D. 2008: jModelTest: Phylogenetic model averaging. Mol. Biol. Evol. 25: 1253-1256.

Puillandre N., Lambert A., Brouillet S. \& Achaz G. 2012: ABGD, Automatic Barcode Gap Discovery for primary species delimitation. - Mol. Ecol. 21: 1864-1877.

Rakauskas R., Rupais A. \& JuRonis V. 1992: The check-list of Lithuanian Aphidoidea. In: New and Rare for Lithuania Insect Species. Records and Descriptions of 1992. Institute of Ecology, Lithuanian Entomological Society, Vilnius, pp. 83-100.

Rakauskas R., Havelka J. \& Bašilova J. 2008: Contribution to the knowledge of the aphid (Hemiptera, Sternorrhyncha: Phylloxeroidea, Aphidoidea) fauna of the Curonian Spit, Lithuania. - Acta Zool. Lituan. 18: 90-107.

Rakauskas R., HavelKa J. \& Bernotienė R. 2014: Mitochondrial (COI) and nuclear (EF-1 $\alpha$ ) DNA variability of Rhopalosiphum padi and Rhopalosiphum nymphaeae (Hemiptera: Aphididae) in Lithuania. - Biologia 69: 1730-1741.

RoNQUiST F. \& HUELSENBECK J.P. 2003: MRBAYES 3: bayesian phylogenetic inference under mixed models. - Bioinformatics 19: $1572-1574$.

StatSoft Inc. 2007: STATISTICA for Windows (Computer Program Manual). Tulsa, USA.

Tzvelev N. 2000: Manual of the Vascular Plants of North - West Russia. Sankt Peterburg State CHF Academy Press, Sankt Peterburg, 782 pp. [in Russian].

VILLESEN P. 2007: FaBox: an online toolbox for fasta sequences. - Mol. Ecol. Resour. 7: 965-968.

Watson G.W., Voegtlin D.J., Murphy S.T. \& Foottit R.G. 1999: Biogeography of the Cinara cupressi complex (Hemiptera: Aphididae) on Cupressaceae, with description of a pest species introduced into Africa. - Bull. Entomol. Res. 89: 271-283.

Wieczorek K., Plachno B.J. \& Swiatek P. 2012: A comparative morphology of the male genitalia of Aphididae (Insecta, Hemiptera): Part 2. - Zoomorphology 131: 303-324.

Wojciechowski W., Depa L., Kanturski M., Wegierek P. \& WiecZOREK K. 2015: An annotated checklist of the Aphids (Hemiptera: Aphidomorpha) of Poland. - Pol. J. Entomol. 84: 383-420.

Wojciechowski W., Depa L., Halgoš J., MateČny J.L. \& KantuRSKI M. 2016: Aphids of Slovakia. KO \& KA, Bratislava, 344 pp.

Zhang J., Kapli P., Pavlidis P. \& Stamatakis A. 2013: A general species delimitation method with applications to phylogenetic placements. — Bioinformatics 29: 2869-2876.

Received October 25, 2019; revised and accepted March 21, 2020 Published online April 28, 2020

Unpaginated supplementary material follows (Tables S1-S3, Figs S1-S2). 
Table SI. Aphid samples used in the molecular analysis.

\begin{tabular}{|c|c|c|c|c|c|c|c|c|c|c|c|c|c|c|c|c|c|c|}
\hline Sample ID & Climatic region & County & Locality & Latitude & Longitude & Collection date & $\begin{array}{c}\text { Host plant } \\
\text { genus }\end{array}$ & $\begin{array}{l}\text { Host plant } \\
\text { species }\end{array}$ & Microhabitat & Aphid genus & Aphid subgenus & Aphid species & Author, year & \begin{tabular}{|c|} 
DNA \\
sample ID
\end{tabular} & COI haplotype & EF-la haplotype & $\begin{array}{c}\text { COI } \\
\text { GB Accession }\end{array}$ & $\begin{array}{c}\text { EFla } \\
\text { GB Accession }\end{array}$ \\
\hline Dal7-320 & Coustal & |Klaipèda & Klaipèda BG & N $55^{\circ} 45^{\prime} 4 "$ & E $21^{\circ} 8^{\prime} 5^{\prime \prime}$ & $24 / 06 / 2017$ & Pinus & aff. nigra & shoots, twigs & Cinara & Cinara & brauni & Börner, 1940 & 536 & (-brauni-2 & E-brauni-3 & МH396419 & MN192225 \\
\hline 12HА03711 & Coustal & Palanga & Palanga BG & no data & no data & 19/08/2012 & Pinus & nigra & shoots, twigs & Cinara & Cinara & brauni & | Börner, 1941 & 555 & C-brauni-3 & E-brauni-2 & MH396418 & MN192226 \\
\hline Ra18-14 & Samogitian & Kretinga & Salantai & N $56^{\circ} 3^{\prime} 31.9^{\prime \prime}$ & E $21^{\circ} 34^{\prime} 11.2^{\prime \prime}$ & $16 / 07 / 2018$ & Pinus & aff. nigra & shoots & Cinara & Cinara & brauni & Börner, 1942 & 670 & C-brauni-1 & E-brauni-2 & MN178356 & MN192227 \\
\hline Da18-321 & Midlith & Raseiniai & Raseiniai & N $55^{\circ} 22^{\prime} 39.9^{\prime \prime}$ & E $23^{\circ} 7^{\prime} 23.7^{\prime \prime}$ & $08 / 07 / 2018$ & Pinus & aff. nigra & shoots, twigs & Cinara & Cinara & brauni & Börner, 1943 & 671 & C-brauni-2 & E-brauni-I & MN178357 & MN192228 \\
\hline Ra 18-5 & Midlith & Pakruojis & Pakruojis & N $55^{\circ} 58^{\prime} 53.23^{\prime \prime}$ & E $23^{\circ} 50^{\prime} 32.23^{\prime \prime}$ & $11 / 07 / 2018$ & Pinus & aff. nigra & shoots & Cinara & Cinara & brauni & Börner, 1944 & 672 & C-brauni-4 & E-brauni-2 & MN178358 & MN192229 \\
\hline Da18-350 & Midlith & Anykščiai & Anykščiai & N $55^{\circ} 31^{\prime} 33.2^{\prime \prime}$ & E $25^{\circ} 6^{\prime} 42.3^{\prime \prime}$ & $18 / 07 / 2018$ & Pinus & aff. nigra & shoots, twigs & Cinara & Cinara & brauni & Börner, 1945 & 673 & (-brauni-5 & E-brauni-2 & MN178359 & MN192230 \\
\hline Da18-373 & Southeast & Molètai & Molètai & N $55^{\circ} 13^{\prime} 42.1^{\prime \prime}$ & E $25^{\circ} 24^{\prime} 34.8^{\prime \prime}$ & $18 / 07 / 2018$ & Pinus & aff. nigra & shoots, twigs & Cinara & Cinara & brauni & Börner, 1946 & 674 & No data & E-brauni-2 & No data & MN192231 \\
\hline Da18-298a & Southeast & Lazdijai & Lazdijai & N $54^{\circ} 14^{\prime} 7.9^{\prime \prime}$ & E $23^{\circ} 30^{\prime} 46.7^{\prime \prime}$ & $23 / 06 / 2018$ & Pinus & aff. nigra & shoots, twigs & Cinara & Cinara & brauni & Börner, 1947 & 675 & C-brauni-2 & E-brauni-2 & MN178360 & MN192232 \\
\hline Da17-186b & Midlith & Panevėžys & Paliūniškis & N $55^{\circ} 48^{\prime} 55^{\prime \prime}$ & E $24^{\circ} 27^{\prime} 13^{\prime \prime}$ & $08 / 06 / 2017$ & Picea & abies & twigs & Cinara & Cinara & costata & (Zefterstedt, 1928) & 676 & (-costata-2 & E-costata-1 & MN178361 & MN192233 \\
\hline Da17-204 & Samogitian & Mažeikiai & Gyvoliai & N $56^{\circ} 11^{\prime} 58^{\prime \prime}$ & E $22^{\circ} 33^{\prime} 8^{\prime \prime}$ & 09/06/2017 & Picea & abies & twigs & Cinara & Cinara & costata & (Zetterstedt, 1928) & 677 & (-costata-1 & E-costata-1 & MN178362 & MN192234 \\
\hline Da17-384 & Coustal & Klaipèda & Endriejavas & N $55^{\circ} 42^{\prime} 12.5^{\prime \prime}$ & E $21^{\circ} 38^{\prime} 7.4^{\prime \prime}$ & $29 / 06 / 2017$ & Picea & abies & twigs & Cinara & Cinara & costata & (Zetterstedt, 1928) & 678 & C-costata-3 & E-costata-1 & MN178363 & MN192235 \\
\hline Da16-357 & Midlith & Prienai & Žydaviškis & N $54^{\circ} 33^{\prime} 12.8^{\prime \prime}$ & E $23^{\circ} 53^{\prime} 24^{\prime \prime}$ & 01/09/2016 & Larix & decidua & shoots, twigs & Cinara & Cinara & cuneomaculata & (del Guercio, 1909) & 523 & C-cuneomaculata-l & No data & MN178364 & No data \\
\hline Da18-270b & Coustal & Klaipèda & Klaipèda & N $55^{\circ} 45^{\prime} 3.3^{\prime \prime}$ & E $21^{\circ} 8^{\prime} 4^{\prime \prime}$ & $15 / 06 / 2018$ & Larix & kaempferi & shoots, twigs & Cinara & Cinara & cuneomaculata & (del Guercio, 1909) & 679 & C-cuneomaculata-2 & E-cuneomaculata-1 & MN178365 & MN192236 \\
\hline Da17-114 & Southeast & Lazdijai & Kapčiamiestis & N $54^{\circ} 0^{\prime} 20.6^{\prime \prime}$ & E $23^{\circ} 38^{\prime} 13.6^{\prime \prime}$ & $31 / 05 / 2017$ & Larix & sp. & shoots, twigs & Cinara & Cinara & cuneomaculata & (del Guercio, 1909) & 681 & C-cuneomaculata-3 & E-cuneomaculata-1 & MN178366 & MN192237 \\
\hline Dal6-072 & Samogitian & Mažeikiai & Gyvoliai & N $56^{\circ} 11^{\prime} 57^{\prime \prime}$ & E $22^{\circ} 33^{\prime} 7^{\prime \prime}$ & 11/06/2016 & Pinus & sy/vestris & shoots, twigs & Cinara & Cinara & hyperophila & (Koch, 1855) & 524 & C-hyperophila-I & E-hyperophila-4 & MN178372 & MN192238 \\
\hline Da17-714 & Coustal & Neringa & Juodkrantè & N $55^{\circ} 30^{\prime} 49.5^{\prime \prime}$ & E $21^{\circ} 6^{\prime} 42.9^{\prime \prime}$ & $16 / 10 / 2017$ & Pinus & sy/vestris & shoots, twigs & Cinara & Cinara & hyperophila & (Koch, 1855) & 553 & C-hyperophila-5 & E-hyperophila-1 & MN178373 & MN192239 \\
\hline Da18-457 & Midlith & Vilkaviškis & Gižai & N $54^{\circ} 37^{\prime} 21.6^{\prime \prime}$ & E $23^{\circ} 12^{\prime} 22.3^{\prime \prime}$ & 05/10/2018 & Pinus & sy/vestris & shoots, twigs & Cinara & Cinara & hyperophila & (Koch, 1855) & 682 & C-hyperophila-5 & E-hyperophila-2 & MN178374 & MN192240 \\
\hline Dal7-189 & Midlith & Panevéžys & Paliūniškis & N $55^{\circ} 48^{\prime} 56^{\prime \prime}$ & E $24^{\circ} 27^{\prime} 12^{\prime \prime}$ & 08/06/2017 & Pinus & sy/vestris & shoots, twigs & Cinara & Cinara & hyperophila & (Koch, 1855) & 683 & C-hyperophila-6 & E-hyperophila-2 & MN178375 & MN192241 \\
\hline Da17-082 & Southeast & Švenčionys & Pabradè & N $54^{\circ} 58^{\prime} 55^{\prime \prime}$ & E $25^{\circ} 48^{\prime} 39^{\prime \prime}$ & $25 / 05 / 2017$ & Pinus & sy/vestris & shoots, twigs & Cinara & Cinara & hyperophila & (Koch, 1855) & 684 & C-hyperophila-7 & E-hyperophila-3 & MN178376 & MN192242 \\
\hline Dal7-386 & Southeast & Elektrènai & Pastrévys & N $54^{\circ} 43^{\prime} 55^{\prime \prime}$ & E $24^{\circ} 40^{\prime}$ I" & 01/07/2017 & Pinus & sy/vestris & shoots, twigs & Cinara & Cinara & hyperophila & (Koch, 1855) & 685 & C-hyperophila-7 & E-hyperophila-2 & MN178377 & MN192243 \\
\hline Dal7-331 & Coustal & Šilutė & Saugos & N $55^{\circ} 28^{\prime} 3^{\prime \prime}$ & E $21^{\circ} 29^{\prime} 22^{\prime \prime}$ & $25 / 06 / 2017$ & Pinus & sylvestris & shoots, twigs & Cinara & Cinara & hyperophila & (Koch, 1855) & 686 & C-hyperophila-8 & E-hyperophila-1 & MN178378 & MN192244 \\
\hline Dal7-351 & Coustal & Palanga & Šventoji & N $56^{\circ} \mathrm{I}^{\prime} 5 \mathrm{I}^{\prime \prime}$ & E $21^{\circ} 7^{\prime} 10^{\prime \prime}$ & 02/06/2017 & Pinus & sylvestris & shoots, twigs & Cinara & Cinara & hyperophila & (Koch, 1855) & 687 & (-hyperophila-2 & E-hyperophila-1 & MN178379 & MN192245 \\
\hline Da18-283 & Samogitian & Plungè & Platakiai & N $56^{\circ} 3^{\prime} 17.6^{\prime \prime}$ & E $21^{\circ} 56^{\prime} 9.6^{\prime \prime}$ & 19/06/2018 & Pinus & sy/vestris & shoots, twigs & Cinara & Cinara & hyperophila & (Koch, 1855) & 688 & C-hyperophila-9 & No data & MN178380 & No data \\
\hline Da18-53 & Southeast & Varèna & Puvočiai & N $54^{\circ} 7^{\prime} 6.7^{\prime \prime}$ & E $24^{\circ} 18^{\prime} 21.8^{\prime \prime}$ & $17 / 05 / 2018$ & Pinus & sy/vestris & shoots, twigs & Cinara & Cinara & hyperophila & (Koch, 1855) & 689 & C-hyperophila-3 & E-hyperophila-l & MN178381 & MN192246 \\
\hline Da18-57a & Southeast & Druskininkai & Leipalingis & N $54^{\circ} 5^{\prime} 9$. l" $^{\prime \prime}$ & E $23^{\circ} 53^{\prime} 16.9^{\prime \prime}$ & $18 / 05 / 2018$ & Pinus & sy/vestris & shoots, twigs & Cinara & Cinara & hyperophila & (Koch, 1855) & 690 & C-hyperophila-4 & E-hyperophila-1 & MN178382 & MN192247 \\
\hline Dal7-550 & Southeast & Lazdijai & Kapčiamiestis & N $54^{\circ} 0^{\prime} 20^{\prime \prime}$ & E $23^{\circ} 38^{\prime} 9^{\prime \prime}$ & 07/08/2017 & Larix & decidua & Stem, branches & Cinara & Cinara & kochiana & (Börner, 1939) & 548 & C-kochiana-1 & E-kochiana-1 & МН396420 & MN192248 \\
\hline Dal7-684 & Southeast & Lazdijai & Kapčiamiestis & N $54^{\circ} 0^{\prime} 20^{\prime \prime}$ & E $23^{\circ} 38^{\prime} 9.1^{\prime \prime}$ & $28 / 09 / 2017$ & Larix & decidua & branches & Cinara & Cinara & Iaricis & (Hartig, 1839) & 550 & C-laricis-1 & E-laricis-3 & МН396421 & MN192249 \\
\hline 12HА03707 & Coustal & Palanga & Palanga BG & no data & no data & $16 / 08 / 2012$ & Larix & decidua & branches & Cinara & Cinara & Iaricis & (Hartig, 1839) & 558 & C-Iaricis-2 & E-laricis-2 & MH396422 & MN192250 \\
\hline Da18-360a & Southeast & Zarasai & Zarasai & N $55^{\circ} 43^{\prime} 56.7^{\prime \prime}$ & E $26^{\circ} 14^{\prime} 43.3^{\prime \prime}$ & $17 / 07 / 2018$ & Larix & sp. & shoots, twigs & Cinara & Cinara & |aricis & (Hartig, 1839) & 680 & (-Iaricis-3 & E-laricis-I & MN178391 & MN192251 \\
\hline
\end{tabular}




\begin{tabular}{|c|c|c|c|c|c|c|c|c|c|c|c|c|c|c|c|c|c|c|}
\hline Da 17-311 & Midlith & Kauno r. & Girionys DA & N $54^{\circ} 51^{\prime} 15^{\prime \prime}$ & E $24^{\circ} 2^{\prime} 45^{\prime \prime}$ & 23/06/2017 & Pinus & mugo & shoots & Cinara & Cinara & neubergi & (Arnhart, 1930) & 604 & C-neubergi-1 & E-neubergi-2 & MH396423 & MN192252 \\
\hline Da 17-356A & Coustal & Klaipèdos m. & Smiltynè & N $55^{\circ} 41^{\prime} 3.1$ " & E $21^{\circ} 7^{\prime} 43.6^{\prime \prime}$ & $27 / 06 / 2017$ & Pinus & mugo & shoots & Cinara & Cinara & neubergi & (Arnhart, 1930) & 606 & C-neubergi-1 & E-neubergi-2 & МH396424 & MN192253 \\
\hline Da 17-436B & Southeast & Vilniaus m. & Kairènai BG & N $54^{\circ} 44^{\prime} 5.2^{\prime \prime}$ & E $25^{\circ} 24^{\prime} 24.6^{\prime \prime}$ & 07/07/2017 & Pinus & mugo & shoots & Cinara & Cinara & neubergi & (Arnhart, 1930) & 610 & C-neubergi-1 & E-neubergi-2 & MH396425 & MN192254 \\
\hline Da 17-515B & Coustal & Neringos & Juodkrantè & N $55^{\circ} 32^{\prime} 35.3^{\prime \prime}$ & E $21^{\circ} 7^{\prime} 20.7^{\prime \prime}$ & $22 / 07 / 2017$ & Pinus & mugo & shoots & Cinara & Cinara & neubergi & (Arnhart, 1930) & 613 & C-neubergi-1 & E-neubergi-2 & МН396426 & MN192255 \\
\hline Ra18-10 & Samogitian & Plungè & Plateliai & N $56^{\circ} 2^{\prime} 49.47^{\prime \prime}$ & N $21^{\circ} 49^{\prime} 5.59^{\prime \prime}$ & $14 / 07 / 2018$ & Pinus & sp. & shoots & Cinara & Cinara & neubergi & (Arnhart, 1930) & 669 & C-neubergi-4 & E-neubergi-4 & MN178395 & MN192256 \\
\hline Da18-363 & Midlith & Rokiškis & Rokiškis & N 555 56' 41.7" & E $25^{\circ} 35^{\prime} 4.9^{\prime \prime}$ & $17 / 07 / 2018$ & Pinus & mugo & shoots & Cinara & Cinara & neubergi & (Arnhart, 1930) & 691 & C-neubergi-I & E-neubergi-1 & MN178396 & MN192257 \\
\hline Da18-372 & Southeast & Molètai & Molètai & N $55^{\circ} 13^{\prime} 40.4^{\prime \prime}$ & E $25^{\circ} 24^{\prime} 34.8^{\prime \prime}$ & $18 / 07 / 2018$ & Pinus & mugo & shoots & Cinara & Cinara & neubergi & (Arnhart, 1930) & 692 & C-neubergi-2 & E-neubergi-3 & MN178397 & MN192258 \\
\hline Da18-301 & Southeast & Lazdijai & Lazdijai & N 5 5 $4^{\circ} 14^{\prime} 7.6^{\prime \prime}$ & E $23^{\circ} 30^{\prime} 49^{\prime \prime}$ & $23 / 06 / 2018$ & Pinus & mugo & shoots & Cinara & Cinara & neubergi & (Arnhart, 1930) & 693 & C-neubergi-1 & E-neubergi-2 & MN178398 & MN192259 \\
\hline Da18-292 & Samogitian & Skuodas & Mosèdis & N $56^{\circ} 9^{\prime} 49.2^{\prime \prime}$ & E $21^{\circ} 34^{\prime} 22.5^{\prime \prime}$ & $20 / 06 / 2018$ & Pinus & mugo & shoots & Cinara & Cinara & neubergi & (Arnhart, 1930) & 694 & C-neubergi-3 & E-neubergi-2 & MN178399 & MN192260 \\
\hline Da18-293 & Samogitian & Mažeikiai & Mažeikiai & N $56^{\circ} 18^{\prime} 50.8^{\prime \prime}$ & E $22^{\circ} 20^{\prime} 42.8^{\prime \prime}$ & 20/06/2018 & Pinus & mugo & shoots & Cinara & Cinara & neubergi & (Arnhart, 1930) & 695 & C-neubergi-1 & E-neubergi-1 & MN178400 & MN192261 \\
\hline Dal6-292 & Coastal & Klaipèda & Klaipèda BG & N $55^{\circ} 45^{\prime} 4^{\prime \prime}$ & E $21^{\circ} 8^{\prime} 5^{\prime \prime}$ & $14 / 06 / 2016$ & Pinus & heldreichii & stem, branches & Cinara & Cinara & nuda & Mordvilko, 1895 & 525 & No data & E-nuda-3 & No data & MN192262 \\
\hline Dal7-328 & Coustal & Šilutė & Saugos & N $55^{\circ} 28^{\prime} 3.3^{\prime \prime}$ & E $21^{\circ} 29^{\prime} 22^{\prime \prime}$ & $25 / 06 / 2017$ & Pinus & sy/vestris & stem & Cinara & Cinara & nuda & Mordvilko, 1896 & 696 & C-nuda-3 & E-nuda-1 & MN178401 & MN192263 \\
\hline Da18-55 & Southeast & Varèna & Puvočiai & N $54^{\circ} 7^{\prime} 7.5^{\prime \prime}$ & E $24^{\circ} 18^{\prime} 16.7^{\prime \prime}$ & $17 / 05 / 2018$ & Pinus & sy/vestris & shoots, twigs & Cinara & Cinara & nuda & Mordvilko, 1897 & 697 & C-nuda-1 & No data & MN178402 & No data \\
\hline Dal7-425 & Southeast & Lazdijai & Kapčiamiestis & N $54^{\circ} 2^{\prime} 24.4^{\prime \prime}$ & E $23^{\circ} 31^{\prime} 52.5^{\prime \prime}$ & 06/07/2017 & Pinus & sy/vestris & stem & Cinara & Cinara & nuda & Mordvilko, 1898 & 698 & C-nuda-2 & E-nuda-l & MN178403 & MN192264 \\
\hline Da17-443 & Southeast & Vilnius & Raudondvaris & N $54^{\circ} 52^{\prime} 43^{\prime \prime}$ & E $25^{\circ} 31^{\prime} 54^{\prime \prime}$ & 07/07/2017 & Pinus & sy/vestris & stem & Cinara & Cinara & nuda & Mordvilko, 1899 & 699 & C-nuda-2 & E-nuda-2 & MN178404 & MN192265 \\
\hline Da18-71 & Midlith & Anykšíiai & Andrioniškkis & N $55^{\circ} 35^{\prime} 0.3^{\prime \prime}$ & E $25^{\circ} 2^{\prime} 15.9^{\prime \prime}$ & $21 / 05 / 2018$ & Pinus & sy/vestris & shoots, twigs & Cinara & Cinara & nuda & Mordvilko, 1900 & 700 & C-nuda-4 & E-nuda-2 & MN178405 & MN192266 \\
\hline Dal7-470 & Midlith & Prienai & Prienlaukys & N $54^{\circ} 35^{\prime} 48^{\prime \prime}$ & E $23^{\circ} 53^{\prime} 24^{\prime \prime}$ & 09/07/2017 & Pinus & sy/vestris & stem, branches & Cinara & Cinara & nuda & Mordvilko, 1901 & 701 & C-nuda-2 & E-nuda-1 & MN178406 & MN192267 \\
\hline Da18-13 & Southeast & Vilkaviškis & Žirgènai & N $54^{\circ} 25^{\prime} 24.2^{\prime \prime}$ & E $22^{\circ} 45^{\prime} 25.1^{\prime \prime}$ & 06/05/2018 & Pinus & sy/vestris & branches & Cinara & Cinara & nuda & Mordvilko, 1902 & 702 & C-nuda-2 & E-nuda-I & MN178407 & MN192268 \\
\hline Dal7-446 & Midlith & Kaunas & VDU BG & N $54^{\circ} 52^{\prime} 12.2^{\prime \prime}$ & E 23 $54^{\prime} 22.2^{\prime \prime}$ & $08 / 07 / 2017$ & Abies & koreana & shoots & Cinara & Cinara & pectinatae & (Nördlinger, 1880) & 543 & C-pectinatae-1 & E-pectinatae-1 & MH396427 & MN192269 \\
\hline Dal6-358 & Midlith & Prienai & Žydaviškis & N $54^{\circ} 33^{\prime} 33^{\prime \prime}$ & E $23^{\circ} 53^{\prime} 14^{\prime \prime}$ & $01 / 09 / 2016$ & Picea & abies & branches & Cinara & Cinara & piceae & (Panzer, 1801) & 526 & C-piceae-2 & E-piceae-4 & MH396434 & MN192270 \\
\hline Dal7-227 & Coustal & Palanga & Būtingè & N $56^{\circ} 7^{\prime} 37^{\prime \prime}$ & E $21^{\circ} 35^{\prime} 25^{\prime \prime}$ & $12 / 06 / 2017$ & Picea & abies & stem, branches & Cinara & Cinara & piceae & (Panzer, 1801) & 533 & C-piceae-1 & E-piceae-2 & MH396431 & MN192271 \\
\hline Dal7-347 & Coustal & Palanga & Šventoji & N $56^{\circ} \mathrm{l}^{\prime} 5 \mathrm{I}^{\prime \prime}$ & E $21^{\circ} 7^{\prime} 10^{\prime \prime}$ & $26 / 06 / 2017$ & Picea & abies & stem, branches & Cinara & Cinara & piceae & (Panzer, 1801) & 538 & C-piceae-1 & E-piceae-3 & MH396430 & MN192272 \\
\hline Da17-353 & Coustal & Palanga & Birutès parkas & N $55^{\circ} 54^{\prime} 22^{\prime \prime}$ & E $21^{\circ} 3^{\prime} 28^{\prime \prime}$ & 26/06/2017 & Picea & abies & branches & Cinara & Cinara & piceae & (Panzer, 1801) & 540 & C-piceae-1 & E-piceae-2 & MH396429 & MN192273 \\
\hline Dal7-445 & Midlith & Kaunas & VDU BS & N $54^{\circ} 52^{\prime} 11.2^{\prime \prime}$ & E 23 $54^{\prime} 16.8^{\prime \prime}$ & $08 / 07 / 2017$ & Picea & abies & stem & Cinara & Cinara & piceae & (Panzer, 1801) & 542 & C-piceae-1 & E-piceae-3 & MH396432 & MN192274 \\
\hline Da17-715 & Coustal & Klaipèda & Klaipèda BG & N $55^{\circ} 45^{\prime} 3.7^{\prime \prime}$ & E $21^{\circ} 8^{\prime} 5.7^{\prime \prime}$ & $17 / 10 / 2017$ & Picea & omorika & twigs & Cinara & Cinara & piceae & (Panzer, 1801) & 554 & C-piceae-3 & E-piceae-2 & MH396428 & MN192275 \\
\hline Ra06-10a & Southeast & Vilnius & Skirgiškès & N $54^{\circ} 50^{\prime} 12.71^{\prime \prime}$ & E $25^{\circ} 22^{\prime} 11.98^{\prime \prime}$ & $31 / 05 / 2006$ & Taxus & baccata & stem, branches & Cinara & Cinara & piceae & (Panzer, 1801) & 599 & C-piceae-1 & E-piceae-1 & MH396433 & MN192276 \\
\hline Da16-034 & Southeast & Visaginas & Visaginas & N $55^{\circ} 34^{\prime} 54^{\prime \prime}$ & E $26^{\circ} 28^{\prime} 40^{\prime \prime}$ & 09/06/2016 & Picea & abies & twigs & Cinara & Cinara & piceicola & (Cholodkovsky, 1896) & 521 & C-piceicola-3 & E-piceicola-4 & MN178408 & MN192277 \\
\hline Da17-076 & Southeast & Vilnius & Raudondvaris & N $54^{\circ} 52^{\prime} 43.5^{\prime \prime}$ & E $25^{\circ} 31^{\prime} 51^{\prime \prime}$ & $25 / 05 / 2017$ & Picea & abies & twigs & Cinara & Cinara & piceicola & (Cholodkovsky, 1896) & 703 & C-piceicola-3 & E-piceicola-3 & MN178409 & MN192278 \\
\hline Da17-091 & Southeast & Utena & Šuminai & N $55^{\circ} 23^{\prime} 52.5^{\prime \prime}$ & E $26^{\circ} 3^{\prime} 40.2^{\prime \prime}$ & $25 / 05 / 2017$ & Picea & abies & twigs & Cinara & Cinara & piceicola & (Cholodkovsky, 1896) & 704 & C-piceicola-l & E-piceicola-2 & MN178410 & MN192279 \\
\hline Da17-159B & Southeast & Vilkaviškis & Pavištytis & N $54^{\circ} 25^{\prime} 33^{\prime \prime}$ & E $22^{\circ} 46^{\prime} 7^{\prime \prime}$ & $05 / 06 / 2017$ & Picea & abies & shoots, twigs & Cinara & Cinara & piceicola & (Cholodkovsky, 1896) & 705 & C-piceicola-3 & E-piceicola-2 & MN178411 & MN192280 \\
\hline Dal7-187 & Midlith & Panevėžys & Paliūniškis & N $55^{\circ} 48^{\prime} 56^{\prime \prime}$ & E $24^{\circ} 27^{\prime} 12^{\prime \prime}$ & $08 / 06 / 2017$ & Picea & abies & shoots, twigs & Cinara & Cinara & piceicola & (Cholodkovsky, 1896) & 706 & C-piceicola-4 & E-piceicola-2 & MN178412 & MN192281 \\
\hline Dal7-214 & Samogitian & Plungè & Platakiai & N $56^{\circ} 2^{\prime} 50.7^{\prime \prime}$ & E $21^{\circ} 57^{\prime} 42.2^{\prime \prime}$ & $10 / 06 / 2017$ & Picea & abies & shoots, twigs & Cinara & Cinara & piceicola & (Cholodkovsky, 1896) & 707 & C-piceicola-l & E-piceicola-2 & MN178413 & MN192282 \\
\hline Da17-322b & Coustal & Klaipèda & Klaipèda & N $55^{\circ} 45^{\prime} 5^{\prime \prime}$ & E $21^{\circ} 8^{\prime} 6^{\prime \prime}$ & $24 / 06 / 2017$ & Picea & monticena & shoots, twigs & Cinara & Cinara & piceicola & (Cholodkovsky, 1896) & 708 & C-piceicola-2 & E-piceicola-1 & MN178414 & MN192283 \\
\hline
\end{tabular}




\begin{tabular}{|c|c|c|c|c|c|c|c|c|c|c|c|c|c|c|c|c|c|c|}
\hline Dal7-108 & Midlith & Kaunas & Girionys & N $55^{\circ} 51^{\prime} 19^{\prime \prime}$ & E $24^{\circ} 2^{\prime} 47^{\prime \prime}$ & 29/05/2017 & Picea & abies & shoots & Cinara & Cinara & pilicornis & (Hartig, 1841) & $566 c$ & C-pilicornis-1 & E-pilicornis-5 & MN178415 & MN192288 \\
\hline Dal7-440a & Southeast & Vilnius & Raudondvaris & |N 54도' $52^{\prime} 44^{\prime \prime}$ & E $25^{\circ} 31^{\prime} 55^{\prime \prime}$ & 07/07/2017 & Picea & abies & shoots & Cinara & Cinara & pilicornis & (Hartig, 1841) & 709 & (-pilicornis-1) & E-pilicornis-1 & MN178416 & MN192284 \\
\hline Da17-509a & Southeast & Utena & Minčia & N $55^{\circ} 28^{\prime} 30^{\prime \prime}$ & E $25^{\circ} 58^{\prime} 37^{\prime \prime}$ & 20/07/2017 & Picea & abies & shoots & Cinara & Cinara & pilicornis & (Hartig, 184l) & $710 \mathrm{c}$ & C-pilicornis-2 & E-pilicornis-7 & MN178417 & MN192290 \\
\hline Da17-171 & Southeast & Vilkaviškis & Pavištytis & N $54^{\circ} 25^{\prime} 33^{\prime \prime}$ & E $22^{\circ} 46^{\prime} 7^{\prime \prime}$ & 05/06/2017 & Picea & abies & shoots & Cinara & Cinara & pilicornis & (Hartig, 184l) & 7110 & (-pilicornis-1 & E-pilicornis-4 & MN178418 & MN192287 \\
\hline Da17-196 & Midlith & Panevėžys & Paliūniškis & N 5 55 50 $50^{\prime} 3^{\prime \prime}$ & E $24^{\circ} 29^{\prime} 41^{\prime \prime}$ & 08/06/2017 & Picea & abies & shoots & Cinara & Cinara & pilicornis & (Hartig, 1841) & 712 & C-pilicornis-3 & E-pilicornis-3 & MN178419 & MN192286 \\
\hline Da17-322a & Coustal & Klaipèda & Klaipèda & N $55^{\circ} 45^{\prime} 5^{\prime \prime}$ & E $21^{\circ} 8^{\prime} 6^{\prime \prime}$ & $24 / 06 / 2018$ & Picea & monticena & shoots & Cinara & Cinara & pilicornis & (Hartig, 1841) & 713 & C-pilicornis-4 & E-pilicornis-6 & MN178420 & MN192289 \\
\hline Dal7-549 & Southeast & Lazdijai & Kapčiamiestis & N $54^{\circ} 2^{\prime} 24^{\prime \prime}$ & E $23^{\circ} 31^{\prime} 28.5^{\prime \prime}$ & 07/08/2017 & Picea & abies & shoots & Cinara & Cinara & pilicornis & (Hartig, 1841) & 714 c & C-pilicornis-1 & E-pilicornis-2 & MN178421 & MN192285 \\
\hline Dal6-032 & Southeast & Utena & Rūgšteliškis & N $55^{\circ} 27^{\prime} 43.7^{\prime \prime}$ & E $26^{\circ} 0^{\prime} 9.6^{\prime \prime}$ & 09/06/2016 & Pinus & sylvestris & shoots & Cinara & Cinara & pilosa & (Zetterstedt, 1840) & 522 & C-pilosa-1 & E-pilosa-1 & MN178422 & MN192291 \\
\hline Da 17-485 & Southeast & Vilkaviškis & Duonelaičiai & N $54^{\circ} 29^{\prime} 17.2^{\prime \prime}$ & E $22^{\circ} 54^{\prime} 20^{\prime \prime}$ & 10/07/2017 & Pinus & sylvestris & shoots & Cinara & Cinara & pilosa & (Zetterstedt, 1840) & 6110 & C-pilosa-l & E-pilosa-4 & MN178423 & MN192292 \\
\hline Da $17-510$ & Southeast & Utena & Rūgšteliškis & N $55^{\circ} 27^{\prime} 43.7^{\prime \prime}$ & E $26^{\circ} 0^{\prime} 9.6^{\prime \prime}$ & $21 / 07 / 2017$ & Pinus & sylvestris & shoots & Cinara & Cinara & pilosa & (Zetterstedt, 1840) & 612 & C-pilosa-2 & E-pilosa-2 & MN178424 & MN192293 \\
\hline Da18-177 & Southeast & Šalčnininkai & Šalčininkèliai & N $54^{\circ} 22^{\prime} 11.1$ " & E $25^{\circ} 22^{\prime} 41.8^{\prime \prime}$ & 05/06/2018 & Pinus & sy/vestris & shoots & Cinara & Cinara & pilosa & (Zetterstedt, 1840) & 7150 & C-pilosa-1 & E-pilosa-3 & MN178425 & MN192294 \\
\hline Da18-202 & Midlith & Jurbarkas & Jurbarkas & N $55^{\circ} 4^{\prime} 40.9^{\prime \prime}$ & E $22^{\circ} 46^{\prime} 36.1^{\prime \prime}$ & $10 / 06 / 2018$ & Pinus & sylvestris & shoots & Cinara & Cinara & pilosa & (Zetterstedt, 1840) & $716 \mathrm{C}$ & C-pilosa-1 & E-pilosa-2 & MN178426 & MN192295 \\
\hline Da18-216 & Coastal & Neringa & Nida & N $55^{\circ} 18^{\prime} 3.2^{\prime \prime}$ & E $21^{\circ} 0^{\prime} 16.4^{\prime \prime}$ & $11 / 06 / 2018$ & Pinus & sy/vestris & shoots & Cinara & Cinara & pilosa & (Zetterstedt, 1840) & $717 \mathrm{C}$ & C-pilosa-1 & E-pilosa-2 & MN178427 & MN192296 \\
\hline Da18-451 & Southeast & Varèna & Musteika & N $53^{\circ} 51^{\prime} 15.7^{\prime \prime}$ & E $24^{\circ} 19^{\prime} 41^{\prime \prime}$ & $27 / 09 / 2018$ & Pinus & sylvestris & shoots & Cinara & Cinara & pilosa & (Zetterstedt, 1840) & $718 \mathrm{C}$ & C-pilosa-1 & E-pilosa-1 & MN178428 & MN192297 \\
\hline Da 17-339A & Coustal & Palanga & Paliepgiriai & N $55^{\circ} 58^{\prime} 45.4^{\prime \prime}$ & E $21^{\circ} 6^{\prime} 13.4^{\prime \prime}$ & $26 / 06 / 2017$ & Pinus & sy/vestris & shoots & Cinara & Cinara & pinea & (Mordvilko, 1895) & $605 \mathrm{C}$ & C-pinea-3 & E-pinea-5 & MN178431 & MN192300 \\
\hline Da 17-374 & Coustal & Neringa & Nida & N $55^{\circ} 18^{\prime} 3^{\prime \prime}$ & E $20^{\circ} 39^{\prime} 26^{\prime \prime}$ & $28 / 06 / 2017$ & Pinus & mugo & shoots & Cinara & Cinara & pinea & (Mordvilko, 1895) & $608 \mathrm{C}$ & C-pinea-4 & E-pinea-2 & MN178432 & MN192301 \\
\hline Da18-146 & Southeast & Zarasai & Tolimènai & N $55^{\circ} 31^{\prime} 24.2^{\prime \prime}$ & E $26^{\circ} 3^{\prime} 24.2^{\prime \prime}$ & $29 / 05 / 2018$ & Pinus & sy/vestris & shoots & Cinara & Cinara & pinea & (Mordvilko, 1895) & 7190 & C-pinea-5 & E-pinea-2 & MN178433 & MN192302 \\
\hline Da18-169 & Midlith & Marijampolè & Marijampolè & N $54^{\circ} 33^{\prime} 8.1^{\prime \prime}$ & E 23을 $20^{\prime} 43.1^{\prime \prime}$ & 04/06/2018 & Pinus & mugo & shoots & Cinara & Cinara & pinea & (Mordvilko, 1895) & $720 \mathrm{C}$ & C-pinea-6 & E-pinea-4 & MN178434 & MN192303 \\
\hline Da17-199 & Midlith & Biržai & Nemunèlio Radviliškis & N $56^{\circ} 24^{\prime} 38.2^{\prime \prime}$ & E $24^{\circ} 48^{\prime} 6.9^{\prime \prime}$ & 09/06/2017 & Pinus & sy/vestris & shoots & Cinara & Cinara & pinea & (Mordvilko, 1895) & 7210 & C-pinea-7 & E-pinea-2 & MN178435 & MN192304 \\
\hline Da18-130 & Samogitian & Plungè & Platakiai & N $56^{\circ} 3^{\prime} 15.7^{\prime \prime}$ & E $21^{\circ} 56^{\prime} 13.8^{\prime \prime}$ & $27 / 05 / 2018$ & Pinus & sy/vestris & shoots & Cinara & Cinara & pinea & (Mordvilko, 1895) & 7220 & C-pinea-8 & E-pinea-l & MN178436 & MN192305 \\
\hline Da17-212 & Samogitian & Mažeikiai & Gyvoliai & N $56^{\circ} 12^{\prime} 24^{\prime \prime}$ & E $22^{\circ} 33^{\prime} 19^{\prime \prime}$ & 09/06/2017 & Pinus & sy/vestris & shoots & Cinara & Cinara & pinea & (Mordvilko, 1895) & $723 \mathrm{C}$ & C-pinea-5 & E-pinea-3 & MN178437 & MN192306 \\
\hline Da18-52 & Southeast & Varèna & Puvočiai & N $54^{\circ} 7^{\prime} 6.7^{\prime \prime}$ & E $24^{\circ} 18^{\prime} 21.8^{\prime \prime}$ & $17 / 05 / 2018$ & Pinus & sylvestris & shoots & Cinara & Cinara & pinea & (Mordvilko, 1895) & $724 \mathrm{C}$ & C-pinea-5 & E-pinea-2 & MN178438 & MN192307 \\
\hline Da18-309 & Southeast & Lazdijai & Kapčiamiestis & N 5 5 ${ }^{\circ} 0^{\prime} 20.3^{\prime \prime}$ & E $23^{\circ} 38^{\prime \prime}$ & 05/07/2018 & Pinus & sylvestris & shoots & Cinara & Cinara & pinea & (Mordvilko, 1895) & $725 \mathrm{C}$ & C-pinea-6 & E-pinea-l & MN178439 & MN192308 \\
\hline Da16-016 & Southeast & Vilnius & Raudondvaris & N $54^{\circ} 52^{\prime} 44^{\prime \prime}$ & E $25^{\circ} 31^{\prime} 59^{\prime \prime}$ & 08/06/2016 & Pinus & sylvestris & shoots, twigs & Cinara & Cinara & pini & (Linnaeus, 1758) & $529 \mathrm{C}$ & C-pini-3 & E-pini-4 & MN178440 & MN192309 \\
\hline Dal6-251 & Southeast & Druskininkai & Švendubrè & N $53^{\circ} 58^{\prime} 48^{\prime \prime}$ & E $23^{\circ} 55^{\prime} 46^{\prime \prime}$ & 20/08/2016 & Pinus & sylvestris & shoots, twigs & Cinara & Cinara & pini & (Linnaeus, 1758) & $568 \mathrm{C}$ & C-pini-4 & E-pini-I & MN17844I & MN192310 \\
\hline Da18-139 & Southeast & Visaginas & Visaginas & N $55^{\circ} 34^{\prime} 55.4^{\prime \prime}$ & E $26^{\circ} 28^{\prime} 38.8^{\prime \prime}$ & $28 / 05 / 2018$ & Pinus & sy/vestris & shoots, twigs & Cinara & Cinara & pini & (Linnaeus, 1758) & $726 \mathrm{C}$ & C-pini-5 & E-pini-2 & MN178442 & MN192311 \\
\hline Da18-170 & Midlith & Marijampolè & Marijampolè & N $54^{\circ} 33^{\prime} 9^{\prime \prime}$ & E $23^{\circ} 20^{\prime} 42.6^{\prime \prime}$ & 04/06/2018 & Pinus & mugo & shoots, twigs & Cinara & Cinara & pini & (Linnaeus, 1758) & $727 \mathrm{C}$ & C-pini-2 & E-pini-2 & MN178443 & MN192312 \\
\hline Da18-389 & Midlith & Akmenè & Akmenè & N $56^{\circ} 14^{\prime} 44.7^{\prime \prime}$ & E 220 44' 52.5" & $24 / 07 / 2018$ & Pinus & sy/vestris & shoots, twigs & Cinara & Cinara & pini & (Linnaeus, 1758) & $728 \mathrm{C}$ & C-pini-1 & E-pini-2 & MN178444 & MN192313 \\
\hline Da17-208 & Samogitian & Mažeikiai & Gyvoliai & N $56^{\circ} 12^{\prime} 24^{\prime \prime}$ & E $22^{\circ} 33^{\prime} 19^{\prime \prime}$ & 09/06/2017 & Pinus & sylvestris & shoots, twigs & Cinara & Cinara & pini & (Linnaeus, 1758) & $729 \mathrm{C}$ & C-pini-6 & E-pini-2 & MN178445 & MN192314 \\
\hline Da17-329 & Coustal & Šilutè & Saugos & N $55^{\circ} 28^{\prime} 3^{\prime \prime}$ & E $21^{\circ} 29^{\prime} 22^{\prime \prime}$ & $25 / 06 / 2017$ & Pinus & sylvestris & shoots & Cinara & Cinara & pini & (Linnaeus, 1758) & $730 \mathrm{C}$ & C-pini-7 & E-pini-3 & MN178446 & MN192315 \\
\hline Dal7-345 & Coustal & Palanga & Šventoji & N $56^{\circ} \mathrm{I}^{\prime} 51$ " & E $21^{\circ} 7^{\prime} 10^{\prime \prime}$ & $26 / 06 / 2017$ & Pinus & sy/vestris & twigs & Cinara & Cinara & pini & (Linnaeus, 1758) & $731 \mathrm{c}$ & C-pini-8 & E-pini-2 & MN178447 & MN192316 \\
\hline Da18-19 & Southeast & Varèna & Puvočiai & N $54^{\circ} 7^{\prime} 7.2^{\prime \prime}$ & E $24^{\circ} 18^{\prime} 17^{\prime \prime}$ & 07/05/2018 & Pinus & sy/vestris & twigs & Cinara & Cinara & pini & (Linnaeus, 1758) & $732 \mathrm{C}$ & C-pini-9 & E-pini-2 & MN178448 & MN192317 \\
\hline Dal7-424 & Southeast & Lazdijai & Kapčiamiestis & N $54^{\circ} 2^{\prime} 24^{\prime \prime}$ & E $23^{\circ} 31^{\prime} 52^{\prime \prime}$ & 06/07/2017 & Pinus & sylvestris & shoots, twigs & Cinara & Cinara & pini & (Linnaeus, 1758) & $733 \mid \mathrm{C}$ & C-pini-2 & E-pini-1 & MN178449 & MN192318 \\
\hline
\end{tabular}




\begin{tabular}{|c|c|c|c|c|c|c|c|c|c|c|c|c|c|c|c|c|c|c|}
\hline Da16-101 & Coustal & Neringa & Alksnynè & no data & no data & $13 / 06 / 2016$ & Pinus & sy/vestris & shoots, twigs & Cinara & Cinara & piniphila & (Ratzeburg, 1844) & 530 & No data & E-piniphila-2 & No data & MN192319 \\
\hline Da17-698 & Coustal & Neringa & Alksnynė & N $55^{\circ} 38^{\prime} 22.3^{\prime \prime}$ & E $21^{\circ} 7^{\prime} 22.3^{\prime \prime}$ & 15/10/2017 & Pinus & sylvestris & shoots, twigs & Cinara & Cinara & piniphila & (Ratzeburg, 1844) & 551 & C-piniphila-2 & E-piniphila-2 & MK829820 & MN192320 \\
\hline Da 17-307 & Southeast & Varèna & Puvočiai & N $54^{\circ} 7^{\prime} 6^{\prime \prime}$ & E $24^{\circ} 18^{\prime} 20^{\prime \prime}$ & $22 / 06 / 2017$ & Pinus & sy/vestris & shoots, twigs & Cinara & Cinara & piniphila & (Ratzeburg, 1844) & 603 & C-piniphila-4 & E-piniphila-5 & MK829821 & MN192321 \\
\hline Da 17-361 & Coastal & Neringa & Alksnynè & N $55^{\circ} 40^{\prime} 53.3^{\prime \prime}$ & E $21^{\circ} 7^{\prime} 10^{\prime \prime}$ & $27 / 06 / 2017$ & Pinus & sy/vestris & shoots, twigs & Cinara & Cinara & piniphila & (Ratzeburg, 1844) & 607 & C-piniphila-2 & E-piniphila-5 & MK829822 & MN192322 \\
\hline Da 17-376 & Coastal & Neringa & Nida & N 55ㅇ $19^{\prime \prime}$ " & E $21^{\circ} 1^{\prime} 16.5^{\prime \prime}$ & $28 / 06 / 2017$ & Pinus & mugo & shoots, twigs & Cinara & Cinara & piniphila & (Ratzeburg, 1844) & 609 & C-piniphila-2 & E-piniphila-5 & MK829823 & MN192323 \\
\hline Da 18-193 & Southeast & Varèna & Puvočiai & N $54^{\circ} 6^{\prime} 52^{\prime \prime}$ & E $24^{\circ} 18^{\prime} 28.1^{\prime \prime}$ & 08/06/2018 & Pinus & sy/vestris & shoots, twigs & Cinara & Cinara & piniphila & (Ratzeburg, 1844) & 734 & C-piniphila-5 & E-piniphila-5 & MN178450 & MN192324 \\
\hline Da18-454 & Southeast & Varèna & Puvočiai & N $54^{\circ} 7^{\prime} 6.3^{\prime \prime}$ & E $24^{\circ} 18^{\prime} 20.2^{\prime \prime}$ & $27 / 09 / 2018$ & Pinus & sy/vestris & shoots, twigs & Cinara & Cinara & piniphila & (Ratzeburg, 1844) & 735 & C-piniphila-1 & E-piniphila-4 & MN178451 & MN192325 \\
\hline Da18-325 & Coustal & Neringa & Alksnynè & N $55^{\circ} 38^{\prime} 4^{\prime \prime}$ & E $21^{\circ} 6^{\prime} 54.3^{\prime \prime}$ & 09/07/2018 & Pinus & sy/vestris & shoots, twigs & Cinara & Cinara & piniphila & (Ratzeburg, 1844) & 736 & C-piniphila-2 & E-piniphila-3 & MN178452 & MN192326 \\
\hline Da18-436 & Coustal & Neringa & Alksnynè & N $55^{\circ} 38^{\prime} 19.9^{\prime \prime}$ & E $21^{\circ} 7^{\prime} 3.7^{\prime \prime}$ & $24 / 09 / 2018$ & Pinus & sy/vestris & shoots, twigs & Cinara & Cinara & piniphila & (Ratzeburg, 1844) & 737 & C-piniphila-2 & E-piniphila-2 & MK829824 & MN192327 \\
\hline Da18-281 & Samogitian & Plungè & Platakiai & N $56^{\circ} 3^{\prime} 17.8^{\prime \prime}$ & E $21^{\circ} 56^{\prime} 11.4^{\prime \prime}$ & 19/06/2018 & Pinus & sy/vestris & shoots, twigs & Cinara & Cinara & piniphila & (Ratzeburg, 1844) & 738 & C-piniphila-2 & E-piniphila-2 & MN178453 & MN192328 \\
\hline Da18-134 & Samogitian & Plungè & Platakiai & N $56^{\circ} 3^{\prime} 17.8^{\prime \prime}$ & E $21^{\circ} 56^{\prime} 11.4^{\prime \prime}$ & $27 / 05 / 2018$ & Pinus & sy/vestris & shoots, twigs & Cinara & Cinara & piniphila & (Ratzeburg, 1844) & 739 & C-piniphila-2 & E-piniphila-2 & MK829825 & MN192329 \\
\hline Da18-140 & Southeast & Visaginas & Visaginas & N $55^{\circ} 34^{\prime} 54.5^{\prime \prime}$ & E $26^{\circ} 28^{\prime} 38^{\prime \prime}$ & $28 / 05 / 2018$ & Pinus & sy/vestris & shoots, twigs & Cinara & Cinara & piniphila & (Ratzeburg, 1844) & 740 & C-piniphila-3 & E-piniphila-1 & MN178454 & MN192330 \\
\hline Da16-355 & Midlith & Kaunas & Dubrava & N $54^{\circ} 48^{\prime} 12^{\prime \prime}$ & E $24^{\circ} 6^{\prime} 50^{\prime \prime}$ & $01 / 09 / 2016$ & Picea & abies & branches & Cinara & Cinara & pruinosa & (Hartig, 1841) & 527 & C-pruinosa-1 & E-pruinosa-7 & MN178455 & MN192331 \\
\hline Dal6-087 & Samogitian & Plungè & Platakiai & N $56^{\circ} 3^{\prime} 18^{\prime \prime}$ & E $21^{\circ} 56^{\prime} 11^{\prime \prime}$ & $12 / 06 / 2016$ & Picea & abies & branches, stem & Cinara & Cinara & pruinosa & (Hartig, 1841) & 531 & C-pruinosa-2 & E-pruinosa-5 & MN178456 & MN192332 \\
\hline Dal7-84 & Southeast & Švenčionys & Pabradè & N $54^{\circ} 58^{\prime} 36.4^{\prime \prime}$ & E $25^{\circ} 55^{\prime} 46.6^{\prime \prime}$ & $25 / 05 / 2017$ & Picea & abies & twigs, branches & Cinara & Cinara & pruinosa & (Hartig, 1841) & 741 & C-pruinosa-1 & E-pruinosa-6 & MN178457 & MN192333 \\
\hline Da17-44lb & Southeast & Vilnius & Raudondvaris & N $54^{\circ} 52^{\prime} 44^{\prime \prime}$ & E $25^{\circ} 31^{\prime} 55^{\prime \prime}$ & 07/07/2017 & Picea & abies & twigs, branches & Cinara & Cinara & pruinosa & (Hartig, 1841) & 742 & C-pruinosa-1 & E-pruinosa-5 & MN178458 & MN192334 \\
\hline Dal7-172 & Southeast & Vilkaviškis & Pavištytis & N $54^{\circ} 25^{\prime} 33^{\prime \prime}$ & E $22^{\circ} 46^{\prime} 77^{\prime \prime}$ & $05 / 06 / 2017$ & Picea & abies & branches & Cinara & Cinara & pruinosa & (Hartig, 1841) & 743 & C-pruinosa-1 & E-pruinosa-4 & MN178459 & MN192335 \\
\hline Dal7-215 & Samogitian & Plungè & Platakiai & N $56^{\circ} 2^{\prime} 50.7^{\prime \prime}$ & E $21^{\circ} 57^{\prime} 42.2^{\prime \prime}$ & $10 / 06 / 2017$ & Picea & abies & branches & Cinara & Cinara & pruinosa & (Hartig, 1841) & 744 & C-pruinosa-3 & E-pruinosa-3 & MN178460 & MN192336 \\
\hline Dal7-355 & Coustal & Palanga & Palanga & N $55^{\circ} 54^{\prime} 22^{\prime \prime}$ & E $21^{\circ} 3^{\prime} 28^{\prime \prime}$ & $26 / 06 / 2017$ & Picea & abies & branches & Cinara & Cinara & pruinosa & (Hartig, 184l) & 745 & C-pruinosa-1 & E-pruinosa-2 & MN178461 & MN192337 \\
\hline Dal7-369 & Coustal & Neringa & Alksnynè & N $55^{\circ} 37^{\prime} 20.6^{\prime \prime}$ & E $21^{\circ} 7^{\prime} 13.2^{\prime \prime}$ & $28 / 06 / 2017$ & Picea & abies & branches & Cinara & Cinara & pruinosa & (Hartig, 1841) & 746 & C-pruinosa-1 & E-pruinosa-l & MN178462 & MN192338 \\
\hline Dal7-449 & Midlith & Kaunas & VDU BS & "N $54^{\circ} 52^{\prime \prime}$ & E $23^{\circ} 54^{\prime} 16^{\prime \prime}$ & $08 / 07 / 2017$ & Thuja & occidentalis & twigs & Cinara & Cupressobium & cupressi & (Buckton, 1881) & 544 & No data & E-cupressi-2 & No data & MN192192 \\
\hline 17HА04527 & Midlith & Kaunas & Girionys & no data & no data & 29/05/2017 & Juniperus & virginiana & shoots & Cinara & Cupressobium & cupressi & (Buckton, 1881) & 563 & C-cupressi-1 & E-cupressi-3 & MN178367 & MN192193 \\
\hline 17НА04521 & Midlith & Kaunas & Girionys & no data & no data & 29/05/2017 & Thuja & occidentalis & shoots & Cinara & Cupressobium & cupressi & (Buckton, 1881) & 564 & C-cupressi-1 & E-cupressi-2 & MN178368 & MN192194 \\
\hline Dal7-232 & Coustal & Klaipèda & Klaipèda & N $55^{\circ} 45^{\prime} 4^{\prime \prime}$ & E $21^{\circ} 8^{\prime} 5^{\prime \prime}$ & $12 / 05 / 2017$ & Thuja & occidentalis & twigs & Cinara & Cupressobium & cupressi & (Buckton, 1881) & 747 & C-cupressi-1 & E-cupressi-2 & MN178369 & MN192195 \\
\hline Da17-213 & Samogitian & Skuodas & Ylakiai & N $56^{\circ} 17^{\prime} 48.7^{\prime \prime}$ & E $21^{\circ} 53^{\prime} 55.2^{\prime \prime}$ & $10 / 06 / 2017$ & Thuja & occidentalis & twigs & Cinara & Cupressobium & cupressi & (Buckton, 1881) & 748 & C-cupressi-1 & E-cupressi-2 & MN178370 & MN192196 \\
\hline Da17-298 & Southeast & Vilnius & Kairènai & N $54^{\circ} 44^{\prime} 5^{\prime \prime}$ & E $25^{\circ} 24^{\prime} 25^{\prime \prime}$ & $22 / 06 / 2017$ & Thuja & occidentalis & twigs & Cinara & Cupressobium & cupressi & (Buckton, 1881) & 749 & C-cupressi-1 & E-cupressi-1 & MN178371 & MN192197 \\
\hline Da16-078 & Samogitian & Skuodas & Šaukliai & N $56^{\circ} 7^{\prime} 36.7^{\prime \prime}$ & E $21^{\circ} 35^{\prime} 25^{\prime \prime}$ & $12 / 06 / 2016$ & Juniperus & communis & shoots & Cinara & Cupressobium & juniperi & (de Geer, 1773) & 520 & C-juniperi-1 & E-juniperi-2 & MN178383 & MN192201 \\
\hline 17 HА04522 & Midlith & Kaunas & Girionys & no data & no data & 29/05/2017 & Juniperus & communis & shoots & Cinara & Cupressobium & juniperi & (de Geer, 1773) & 562 & C-juniperi-2 & E-juniperi-6 & MN178384 & MN192202 \\
\hline Da17-92 & Southeast & Utena & Šuminai & N $55^{\circ} 23^{\prime} 52^{\prime \prime}$ & E $26^{\circ} 3^{\prime} 40^{\prime \prime}$ & $25 / 05 / 2017$ & Juniperus & communis & shoots & Cinara & Cupressobium & juniperi & (de Geer, 1773) & 750 & C-juniperi-8 & E-juniperi-5 & MN178385 & MN192203 \\
\hline Dal7-296 & Southeast & Vilnius & Kairènai & N $54^{\circ} 44^{\prime} 5^{\prime \prime}$ & E $25^{\circ} 24^{\prime} 25^{\prime \prime}$ & $21 / 06 / 2017$ & Juniperus & communis & shoots & Cinara & Cupressobium & juniperi & (de Geer, 1773) & 751 & C-juniperi-3 & E-juniperi-4 & MN178386 & MN192204 \\
\hline Dal7-197 & Midlith & Biržai & Papilys & N $56^{\circ} 7^{\prime} 55.5^{\prime \prime}$ & E $25^{\circ} 4^{\prime} 5.5^{\prime \prime}$ & 09/06/2017 & Juniperus & communis & shoots & Cinara & Cupressobium & juniperi & (de Geer, 1773) & 752 & No data & E-juniperi-3 & No data & MN192205 \\
\hline Dal7-30 & Southeast & Lazdijai & Kapčiamiestis & N $54^{\circ} 2^{\prime} 48^{\prime \prime}$ & E $23^{\circ} 31^{\prime} 38.5^{\prime \prime}$ & $18 / 05 / 2017$ & Juniperus & communis & shoots & Cinara & Cupressobium & juniperi & (de Geer, 1773) & 754 & C-juniperi-4 & E-juniperi-3 & MN178387 & MN192206 \\
\hline Da18-4l & Southeast & Varèna & Musteika & N $53^{\circ} 57^{\prime} 41.2^{\prime \prime}$ & E $24^{\circ} 22^{\prime} 58^{\prime \prime}$ & $17 / 05 / 2018$ & Juniperus & communis & shoots & Cinara & cupressobium & juniperi & (de Geer, 1773) & 755 & C-juniperi-5 & E-juniperi-2 & MN178388 & MN192207 \\
\hline
\end{tabular}




\begin{tabular}{|c|c|c|c|c|c|c|c|c|c|c|c|c|c|c|c|c|c|c|}
\hline Da18-285 & Samogitian & Skuodas & Šaukliai & N $56^{\circ} 7^{\prime} 36.7^{\prime \prime}$ & E $21^{\circ} 35^{\prime} 25^{\prime \prime}$ & $20 / 06 / 2018$ & Juniperus & communis & shoots & Cinara & Cupressobium & juniperi & (de Geer, 1773) & 756 & C-juniperi-6 & E-juniperi-7 & MN178389 & MN192208 \\
\hline Dal7-342 & Coustal & Palanga & Šventoji & N $56^{\circ} \mathrm{I}^{\prime}$ & E $21^{\circ} 7^{\prime} 10^{\prime \prime}$ & $26 / 06 / 2017$ & Juniperus & communis & shoots & Cinara & Cupressobium & juniperi & (de Geer, 1773) & 757 & C-juniperi-7 & E-juniperi-1 & MN178390 & MN192209 \\
\hline Dal7-028 & Southeast & Lazdijai & Ivoškai & N $54^{\circ} 2^{\prime} 47.3^{\prime \prime}$ & E $23^{\circ} 31^{\prime} 38.3^{\prime \prime}$ & $18 / 05 / 2017$ & Juniperus & communis & branches, stem & Cinara & Cupressobium & mordvlkoi & (Pašek, 1954) & 532 & C-mordvilkoi-1 & E-mordvilkoi-1 & MN178392 & MN192198 \\
\hline Dal7-427 & Southeast & Lazdijai & Ivoškai & N $54^{\circ} 0^{\prime} 45.4^{\prime \prime}$ & E $23^{\circ} 30^{\prime} 34.6^{\prime \prime}$ & 06/07/2017 & Juniperus & communis & root collar & Cinara & Cupressobium & mordvkoi & (Pašek, 1954) & 541 & (-mordvilkoi-1 & E-mordvilkoi-1 & MN178393 & MN192199 \\
\hline Dal7-680 B & Southeast & Varèna & Margionys & N $53^{\circ} 59^{\prime} 34.9^{\prime \prime}$ & E $24^{\circ} 16^{\prime} 31.9^{\prime \prime}$ & $28 / 09 / 2017$ & Juniperus & communis & twigs & Cinara & Cupressobium & mordvlkoi & (Pašek, 1954) & 549 & (-mordvilkoi-I & E-mordvilkoi-1 & MN178394 & MN192200 \\
\hline Dal7-318 & Midlith & Kaunas & Girionys & N $55^{\circ} 51^{\prime} 19^{\prime \prime}$ & E $24^{\circ} 2^{\prime} 47^{\prime \prime}$ & $23 / 06 / 2017$ & Pinus & nigra & needles & Cinara & Schizolachnus & obscura & Börner, 1940 & 569 & C-obscurus-1 & E-obscurus-4 & MN178474 & MN192339 \\
\hline Da18-244 & Coustal & Neringa & Pervalka & N $55^{\circ} 24^{\prime} 51.3^{\prime \prime}$ & E $21^{\circ} 5^{\prime} 40.2^{\prime \prime}$ & $13 / 06 / 2018$ & Pinus & aff. nigra & needles & Cinara & Schizolachnus & obscura & Börner, 1941 & 759 & C-obscurus-1 & E-obscurus-2 & MN178475 & MN192340 \\
\hline Da18-258b & Coustal & Neringa & Juodkrantè & N $55^{\circ} 32^{\prime} 41^{\prime \prime}$ & E $21^{\circ} 7^{\prime} 18.6^{\prime \prime}$ & $14 / 06 / 2018$ & Pinus & Pinus nigra & needles & Cinara & Schizolachnus & obscura & Börner, 1942 & 761 & C-obscurus-1 & E-obscurus-1 & MN178476 & MN192341 \\
\hline Da18-326 & Coustal & Neringa & Alksnynè & N $55^{\circ} 38^{\prime} 4.6^{\prime \prime}$ & E $21^{\circ} 6^{\prime} 54.9^{\prime \prime}$ & 09/07/2018 & Pinus & sy/vestris & needles & Cinara & Schizolachnus & obscura & Börner, 1943 & 769 & No data & E-obscurus-5 & No data & MN192342 \\
\hline Da18-254b & Coustal & Neringa & Juodkrantè & N $55^{\circ} 31^{\prime} 58.1^{\prime \prime}$ & E $21^{\circ} 7^{\prime} 8.2^{\prime \prime}$ & $14 / 06 / 2018$ & Pinus & aff. nigra & needles & Cinara & Schizolachnus & obscura & Börner, 1944 & 775 & C-obscurus-1 & E-obscurus-3 & MN178477 & MN192343 \\
\hline Dal7-457 & Southeast & Elektrènai & Geibonys & N $54^{\circ} 45^{\prime} 44.8^{\prime \prime}$ & E $24^{\circ} 41^{\prime} 27.5^{\prime \prime}$ & 08/07/2017 & Pinus & sy/vestris & needles & Cinara & Schizolachnus & pineti & (Fabricius, 1781) & 570 & C-pineti-4 & E-pineti-1 & MN178478 & MN192344 \\
\hline Dal7-74 & Southeast & Vilnius & Raudondvaris & N $54^{\circ} 52^{\prime} 43^{\prime \prime}$ & E $25^{\circ} 31^{\prime} 51^{\prime \prime}$ & $25 / 05 / 2017$ & Pinus & sy/vestris & needles & Cinara & Schizolachnus & pineti & (Fabricius, 1781) & 7621 & No data & E-pineti-1 & No data & MN192345 \\
\hline Da18-149a & Southeast & Utena & Rūgšteliškis & N $55^{\circ} 27^{\prime} 43.7^{\prime \prime}$ & E $26^{\circ} 0^{\prime} 9.6^{\prime \prime}$ & $29 / 05 / 2018$ & Pinus & sy/vestris & needles & Cinara & Schizolachnus & pineti & (Fabricius, 1781) & 7631 & No data & E-pineti-1 & No data & MN192346 \\
\hline Da18-151 & Midlith & Kalvarija & Jurgežeriai & N $54^{\circ} 24^{\prime} 54.4^{\prime \prime}$ & E $23^{\circ} 9^{\prime} 37.5^{\prime \prime}$ & $31 / 05 / 2018$ & Pinus & sy/vestris & needles & Cinara & Schizolachnus & pineti & (Fabricius, 1781) & 764 & C-pineti-1 & E-pineti-1 & MN178479 & MN192347 \\
\hline Da18-317b & Midlith & Kèdainiai & Skinderiškis & N $55^{\circ} 18^{\prime} 58.1^{\prime \prime}$ & E $23^{\circ} 39^{\prime} 11.7^{\prime \prime}$ & 08/07/2018 & Pinus & mugo & needles & Cinara & Schizolachnus & pineti & (Fabricius, 1781) & 765 & C-pineti-1 & E-pineti-1 & MN178480 & MN192348 \\
\hline Da17-301b & Southeast & Varèna & Musteika & N $53^{\circ} 57^{\prime} 40^{\prime \prime}$ & E $24^{\circ} 21^{\prime} 59^{\prime \prime}$ & $22 / 06 / 2017$ & Pinus & sy/vestris & needles & Cinara & Schizolachnus & pineti & (Fabricius, 1781) & 766 & C-pineti-1 & E-pineti-1 & MN178481 & MN192349 \\
\hline Da18-298b & Southeast & Lazdijai & Lazdijai & N $54^{\circ} 14^{\prime} 7.9^{\prime \prime}$ & E $23^{\circ} 30^{\prime} 46.7^{\prime \prime}$ & $23 / 06 / 2018$ & Pinus & aff. nigra & needles & Cinara & Schizolachnus & pineti & (Fabricius, 1781) & 767 & C-pineti-2 & E-pineti-2 & MN178482 & MN192350 \\
\hline Da17-330 & Coustal & Šilutè & Saugos & N $55^{\circ} 28^{\prime} 3^{\prime \prime}$ & E $21^{\circ} 29^{\prime} 22^{\prime \prime}$ & $25 / 06 / 2017$ & Pinus & sy/vestris & needles & Cinara & Schizolachnus & pineti & (Fabricius, 1781) & 768 & C-pineti-3 & E-pineti-1 & MN178483 & MN192351 \\
\hline Dal7-312 & Midlith & Kaunas & Girionys & N $55^{\circ} 51^{\prime} 19^{\prime \prime}$ & E $24^{\circ} 2^{\prime} 47^{\prime \prime}$ & $23 / 06 / 2017$ & Pinus & sy/vestris & needles & Eulachnus & & agilis & (Kaltenbach, 1843) & 534 & C-agilis-1 & E-agilis-5 & MN178463 & MN192210 \\
\hline Dal7-348 & Coustal & Palanga & Šventoji & N $56^{\circ} \mathrm{I}^{\prime} 5 \mathrm{I}^{\prime \prime}$ & E $21^{\circ} 7^{\prime} 10^{\prime \prime}$ & $26 / 06 / 2017$ & Pinus & sy/vestris & needles & Eulachnus & & agilis & (Kaltenbach, 1843) & 539 & C-agilis-2 & E-agilis-4 & MN178464 & MN192211 \\
\hline Dal7-462 & Southeast & Trakai & Aukštadvaris & N $54^{\circ} 35^{\prime} 19.4^{\prime \prime}$ & E $24^{\circ} 31^{\prime} 29.5^{\prime \prime}$ & 09/07/2017 & Pinus & sy/vestris & needles & Eulachnus & & agilis & (Kaltenbach, 1843) & 545 & C-agilis-3 & E-agilis-3 & MN178465 & MN192212 \\
\hline 12НАОЗ3889 & Southeast & Molètai & Kraujeliai & no data & no data & 10/07/2012 & Pinus & sy/vestris & needles & Eulachnus & & agilis & (Kaltenbach, 1843) & 565 & C-agilis-4 & E-agilis-2 & MN178466 & MN192213 \\
\hline Da18-369b & Southeast & Molètai & Molètai & N $55^{\circ} 13^{\prime} 53^{\prime \prime}$ & E $25^{\circ} 25^{\prime} 10^{\prime \prime}$ & $18 / 07 / 2018$ & Pinus & mugo & needles & Eulachnus & & agilis & (Kaltenbach, 1843) & 770 & C-agilis-3 & E-agilis-1 & MN178467 & MN192214 \\
\hline Dal7-524 & Coustal & Neringa & Alksnynè & N $55^{\circ} 38^{\prime} 11.3^{\prime \prime}$ & E $21^{\circ} 7^{\prime} 1.5^{\prime \prime}$ & $22 / 07 / 2017$ & Pinus & sy/vestris & needles & Eulachnus & & brevipilosus & Börner, 1940 & 546 & C-brevipilosus-1 & E-brevipilosus-1 & MH396417 & MN192215 \\
\hline Da17-528 A & Coustal & Palanga & Būtingè & N $56^{\circ} 4^{\prime} 22.1^{\prime \prime}$ & E $21^{\circ} 7^{\prime} 19.6^{\prime \prime}$ & $22 / 07 / 2017$ & Pinus & sy/vestris & needles & Eulachnus & & brevipilosus & Börner, 1941 & 547 & C-brevipilosus-1 & E-brevipilosus-1 & MH396416 & MN192216 \\
\hline Da17-710 & Coustal & Neringa & Alksnynè & N $55^{\circ} 38^{\prime} 5^{\prime \prime}$ & E $21^{\circ} 6^{\prime} 57^{\prime \prime}$ & $15 / 10 / 2017$ & Pinus & sy/vestris & needles & Eulachnus & & brevipilosus & Börner, 1942 & 552 & C-brevipilosus-1 & E-brevipilosus-1 & MH396415 & MN192217 \\
\hline Da18-359b & Southeast & Zarasai & Zarasai & N $55^{\circ} 43^{\prime} 58.8^{\prime \prime}$ & E $26^{\circ} 14^{\prime} 50.4^{\prime \prime}$ & $17 / 07 / 2018$ & Pinus & mugo & needles & Eulachnus & & brevipilosus & Börner, 1943 & 772 & C-brevipilosus-1 & E-brevipilosus-1 & MN178468 & MN192218 \\
\hline \begin{tabular}{|l} 
Da18-456b \\
\end{tabular} & Midlith & Vilkaviškis & Gižai & N $54^{\circ} 37^{\prime} 21.6^{\prime \prime}$ & E $23^{\circ} 12^{\prime} 22.1^{\prime \prime}$ & 05/10/2018 & Pinus & sy/vestris & needles & Eulachnus & & brevipilosus & Börner, 1944 & 773 & C-brevipilosus-1 & E-brevipilosus-1 & MN178469 & MN192219 \\
\hline Dal7-324 & Coustal & Klaipèda & Klaipèda BG & N $55^{\circ} 45^{\prime} 4^{\prime \prime}$ & E $21^{\circ} 8^{\prime} 5^{\prime \prime}$ & $24 / 06 / 2017$ & Pinus & heldreichii & needles & Eulachnus & & nigricola & (Pašek, 1953) & 537 & C-nigricola-l & E-nigricola-l & MH396414 & MN192220 \\
\hline Da18-254 & Coustal & Neringa & Juodkrantè & N $55^{\circ} 31^{\prime \prime} 58.1^{\prime \prime}$ & E $21^{\circ} 7^{\prime} 8.2^{\prime \prime}$ & $14 / 06 / 2018$ & Pinus & aff. nigra & needles & Eulachnus & & rileyi & (Williams, 1911) & 760 & C-rileyi-1 & E-rileyi-I & MN178470 & MN192221 \\
\hline Da18-253b & Coustal & Neringa & Juodkrantè & N $55^{\circ} 33^{\prime} 25.5^{\prime \prime}$ & E $21^{\circ} 6^{\prime} 59.7^{\prime \prime}$ & $14 / 06 / 2018$ & Pinus & aff. nigra & needles & Eulachnus & & rileyi & (Williams, 1911) & 774 & C-rileyi-2 & E-rileyi-3 & MN178471 & MN192222 \\
\hline Da18-458a & Midlith & Vilkaviškis & Gižai & N $54^{\circ} 37^{\prime} 21.7^{\prime \prime}$ & E $23^{\circ} 12^{\prime} 21.1^{\prime \prime}$ & $05 / 10 / 2018$ & Pinus & sy/vestris & needles & Eulachnus & & rileyi & (Williams, 1911) & 776 & C-rileyi-3 & E-rileyi-2 & MN178472 & MN192223 \\
\hline Da18-369c & Southeast & Molėtai & Molètai & N $55^{\circ} 13^{\prime} 53^{\prime \prime}$ & E $25^{\circ} 25^{\prime} 10^{\prime \prime}$ & $18 / 07 / 2018$ & Pinus & mugo & needles & Eulachnus & & rileyi & (Williams, 1911) & 777 & (-rileyi-I & E-rileyi-I & MN178473 & MN192224 \\
\hline
\end{tabular}


Table S2. Species delimitation results using Automatic Barcode Gap Discovery (ABGD), General Mixed Yule Coalescent (GMYC)

model and Poisson Tree Processes (PTP) methods based on COI fragment data. Species names are given in accordance with morphospecies identification results. DNA sample ID numbers are the same as in Table S1.

\begin{tabular}{|c|c|c|c|}
\hline $\begin{array}{c}\text { Morphology and ecology } \\
\text { based species identification }\end{array}$ & ABGD COI & GMYC COI & PTP COI BI \\
\hline $\begin{array}{c}\text { Cinara (Cinara) pectinatae } \\
\mathrm{n}=1\end{array}$ & 543 & 543 & 543 \\
\hline \multirow{3}{*}{$\begin{array}{c}\text { Cinara } \\
\text { (Cupressobium) juniperi } \\
\mathrm{n}=8\end{array}$} & \multirow{3}{*}{$\begin{array}{c}520,562,750,751,754,755 \\
756,757\end{array}$} & $755,562,751$ & 562,751 \\
\hline & & \multirow{2}{*}{$757,756,520,754,750$} & 755 \\
\hline & & & $750,754,757,520,756$ \\
\hline $\begin{array}{c}\text { Cinara (Cupressobium) mordvilkoi } \\
\mathrm{n}=3\end{array}$ & $532,541,549$ & $549,532,541$ & $532,541,549$ \\
\hline $\begin{array}{c}\text { Cinara (Cupressobium) cupressi } \\
\mathrm{n}=5\end{array}$ & $563,564,747,748,749$ & $749,748,747,564,563$ & $563,564,747,748,749$ \\
\hline $\begin{array}{l}\text { Cinara (Cinara) kochiana } \\
\mathrm{n}=1\end{array}$ & 548 & \multirow{2}{*}{$\begin{array}{c}\text { C. (C.) kochiana } \\
548 \\
\text { C. (C.) laricis } \\
550,558\end{array}$} & 548 \\
\hline \multirow{2}{*}{$\begin{array}{l}\text { Cinara (Cinara) laricis } \\
\qquad \mathrm{n}=3\end{array}$} & \multirow{4}{*}{$\begin{array}{c}\text { C. }(C .) \text { laricis } \\
550,558,680 \\
\text { C. }(C .) \text { cuneomaculata } \\
523,679,681\end{array}$} & & 550,558 \\
\hline & & 680 & 680 \\
\hline \multirow{2}{*}{$\begin{array}{c}\text { Cinara (Cinara) cuneomaculata } \\
\mathrm{n}=3\end{array}$} & & \multirow{2}{*}{$679,523,681$} & 681 \\
\hline & & & 523,679 \\
\hline \multirow{2}{*}{$\begin{array}{l}\text { Cinara (Cinara) costata } \\
\mathrm{n}=3\end{array}$} & \multirow{2}{*}{$677,676,678$} & \multirow{2}{*}{$678,676,677$} & 677 \\
\hline & & & 676,678 \\
\hline $\begin{array}{l}\text { Cinara }(\text { Cinara }) \text { piceae } \\
\mathrm{n}=7\end{array}$ & $\begin{array}{c}599,533,538,540,542,554 \\
526\end{array}$ & $\begin{array}{c}554,540,533,538,542,599 \\
526\end{array}$ & $\begin{array}{c}599,526,533,538,540,542, \\
554\end{array}$ \\
\hline $\begin{array}{c}\text { Cinara (Cinara) piceicola } \\
\mathrm{n}=7\end{array}$ & $\begin{array}{c}521,703,704,705,706,707 \\
708\end{array}$ & $\begin{array}{c}705,521,708,703,704,707 \\
706\end{array}$ & $\begin{array}{c}521,703,705,706,708,704, \\
707\end{array}$ \\
\hline $\begin{array}{c}\text { Cinara (Cinara) pilicornis } \\
\mathrm{n}=7\end{array}$ & $\begin{array}{c}566,709,710,711,712,713, \\
714\end{array}$ & $\begin{array}{c}709,710,712,566,713,714 \\
711\end{array}$ & $\begin{array}{c}566,709,710,711,712,713, \\
714\end{array}$ \\
\hline $\begin{array}{c}\text { Cinara (Cinara) pruinosa } \\
\mathrm{n}=8\end{array}$ & $\begin{array}{c}527,531,741,742,743,744 \\
745,746\end{array}$ & $\begin{array}{c}531,741,743,745,746,742 \\
527,744\end{array}$ & $\begin{array}{c}527,531,741,742,743,744, \\
745,746\end{array}$ \\
\hline $\begin{array}{l}\text { Cinara }(\text { Cinara }) \text { brauni } \\
\mathrm{n}=7\end{array}$ & $536,555,670,671,672,673,675$ & $\begin{array}{c}675,673,671,672,536,555 \\
670\end{array}$ & $\begin{array}{l}536,555,670,671 \\
\quad 672,673,675\end{array}$ \\
\hline
\end{tabular}




\begin{tabular}{|c|c|c|c|}
\hline \multirow{5}{*}{$\begin{array}{l}\text { Cinara (Cinara) hyperophila } \\
\mathrm{n}=11\end{array}$} & $\begin{array}{c}524,553,682,683,684,685 \\
686,687,689,690\end{array}$ & $\begin{array}{c}685,684,553,682,683,686 \\
687,524,690\end{array}$ & $\begin{array}{c}690,553,682,683,686,684, \\
685\end{array}$ \\
\hline & \multirow{4}{*}{688} & \multirow{4}{*}{688,689} & 688 \\
\hline & & & 689 \\
\hline & & & 524 \\
\hline & & & 687 \\
\hline $\begin{array}{c}\text { Cinara (Cinara) neubergi } \\
\mathrm{n}=10\end{array}$ & $\begin{array}{c}604,606,610,613,669,691 \\
692,693,695,694\end{array}$ & $\begin{array}{c}606,610,691,694,613,669 \\
695,693,604\end{array}$ & $\begin{array}{c}604,606,610,613,669,691, \\
692,693,694,695\end{array}$ \\
\hline $\begin{array}{l}\text { Cinara (Cinara) nuda } \\
\mathrm{n}=7\end{array}$ & $\begin{array}{c}696,697,698,699,700,701 \\
702\end{array}$ & $\begin{array}{c}696,700,699,702,698,701 \\
697\end{array}$ & $\begin{array}{c}696,697,698,699,700,701, \\
702\end{array}$ \\
\hline $\begin{array}{c}\text { Cinara (Cinara) pilosa } \\
\mathrm{n}=7\end{array}$ & $\begin{array}{c}522,611,612,715,716,717 \\
718\end{array}$ & $611,612,717,522,718,715,716$ & $\begin{array}{c}522,611,612,715,716,717, \\
718\end{array}$ \\
\hline \multirow{2}{*}{$\begin{array}{l}\text { Cinara }(\text { Cinara }) \text { pinea } \\
\mathrm{n}=8\end{array}$} & \multirow{3}{*}{$\begin{array}{c}\text { C. }(C .) \text { pinea } \\
608,720,721,722,725,719 \\
723,724 \\
\text { C. }(C .) \text { piniphila } \\
551,603,607,609,737,739 \\
734,735,736,738,740,605\end{array}$} & $\begin{array}{c}\text { C. }(C .) \text { pinea } \\
608,724,723,719 \\
\end{array}$ & \multirow{3}{*}{$\begin{array}{c}\text { C. }(C .) \text { pinea } \\
608,721,719,723,724,720, \\
722,725 \\
\text { C. }(C .) \text { piniphila } \\
551,607,609,737,739,736, \\
738,603,605,735,734,740\end{array}$} \\
\hline & & $\begin{array}{c}C .(C .) \text { pinea } \\
720,721,722,725\end{array}$ & \\
\hline $\begin{array}{l}\text { Cinara (Cinara) piniphila } \\
\qquad \mathrm{n}=12\end{array}$ & & $\begin{array}{c}C .(C .) \text { piniphila } \\
551,603,605,607,609,734 \text {, } \\
735,736,737,738,739,740\end{array}$ & \\
\hline \multirow{2}{*}{$\begin{array}{c}\text { Cinara (Cinara) pini } \\
\mathrm{n}=10\end{array}$} & \multirow{2}{*}{$\begin{array}{c}529,568,726,727,728,729 \\
730,731,732,733\end{array}$} & $726,529,729,732,730,568$ & \multirow{2}{*}{$\begin{array}{c}726,727,728,731,733,529, \\
729,732,568,730\end{array}$} \\
\hline & & $731,733,727,728$ & \\
\hline $\begin{array}{c}\text { Cinara (Schizolachnus) obscura } \\
\mathrm{n}=4\end{array}$ & \multirow{2}{*}{$\begin{array}{c}\text { C. }(S .) \text { obscurus } \\
569,759,761,775 \\
\text { C. }(S .) \text { pineti } \\
570,764,765,766,767,768\end{array}$} & $761,569,775,759$ & $569,759,761,775$ \\
\hline $\begin{array}{c}\text { Cinara (Schizolachnus) pineti } \\
\mathrm{n}=6\end{array}$ & & $768,764,766,765,570$ I, 767 & 767, 570I, 764, 765, 766, 768 \\
\hline $\begin{array}{l}\begin{array}{l}\text { Eulachnus agilis } \\
\mathrm{n}=5\end{array} \\
\end{array}$ & $534,539,545,565,770$ & $545,534,770,565,539$ & $534,539,545,565,770$ \\
\hline $\begin{array}{l}\text { Eulachnus brevipilosus } \\
\mathrm{n}=5\end{array}$ & $546,547,552,772,773$ & $546,772,552,547,773$ & $546,547,552,772,773$ \\
\hline $\begin{array}{l}\text { Eulachnus nigricola } \\
\mathrm{n}=1\end{array}$ & 537 & 537 & 537 \\
\hline $\begin{array}{c}\text { Eulachnus rileyi } \\
\mathrm{n}=4\end{array}$ & $760,774,776,777$ & $774,760,777,776$ & $760,774,776,777$ \\
\hline
\end{tabular}


Table S3. Species delimitation results using Automatic Barcode Gap Discovery (ABGD), General Mixed Yule Coalescent (GMYC)

model and Poisson Tree Processes (PTP) methods based on EF-1 $\alpha$ fragment data. Species names are given in accordance with morphospecies identification results. DNA sample ID numbers are the same as in Table S1.

\begin{tabular}{|c|c|c|c|}
\hline $\begin{array}{l}\text { Morphology and ecology } \\
\text { based species identification }\end{array}$ & ABGD EF-1 $\alpha$ & GMYC EF-1 $\alpha$ & PTP EF-1 $\alpha$ BI \\
\hline $\begin{array}{c}\text { Cinara (Cinara) pectinatae } \\
\mathrm{n}=1\end{array}$ & 543 & 543 & 543 \\
\hline \multirow{4}{*}{$\begin{array}{c}\text { Cinara (Cupressobium) juniperi } \\
\mathrm{n}=8\end{array}$} & 562,751 & $562,752,754,756$ & \multirow{2}{*}{$\begin{array}{c}562,756,752,754,750,520, \\
755,751,757 \\
\end{array}$} \\
\hline & $752,754,750,520,755$ & \multirow{3}{*}{$750,751,757,520$} & \\
\hline & 756 & & \\
\hline & 757 & & \\
\hline $\begin{array}{c}\text { Cinara (Cupressobium) mordvilkoi } \\
\mathrm{n}=3\end{array}$ & $549,541,532$ & $549,541,532$ & $532,541,549$ \\
\hline \multirow{3}{*}{$\begin{array}{c}\text { Cinara }(\text { Cupressobium) cupressi } \\
\mathrm{n}=6\end{array}$} & 749 & \multirow{3}{*}{$748,544,749,747,564,563$} & \multirow{2}{*}{749} \\
\hline & 563 & & \\
\hline & $544,564,747,748$ & & $544,563,564,747,748$ \\
\hline $\begin{array}{l}\text { Cinara (Cinara) kochiana } \\
\mathrm{n}=1\end{array}$ & 548 & 548 & 548 \\
\hline $\begin{array}{c}\text { Cinara (Cinara) cuneomaculata } \\
\mathrm{n}=2\end{array}$ & 679,681 & 679,681 & 679,681 \\
\hline $\begin{array}{c}\text { Cinara } \\
\mathrm{n}=3\end{array}$ & $550,680,558$ & $550,680,558$ & $550,558,680$ \\
\hline $\begin{array}{l}\text { Cinara (Cinara) costata } \\
\mathrm{n}=3\end{array}$ & $678,676,677$ & $678,676,677$ & $676,677,678$ \\
\hline \multirow{2}{*}{$\begin{array}{c}\text { Cinara }(\text { Cinara }) \text { piceae } \\
\mathrm{n}=7\end{array}$} & \multirow{2}{*}{$\begin{array}{c}533,540,526,554,599,542 \\
538\end{array}$} & \multirow{2}{*}{$\begin{array}{c}533,540,526,554,599,542, \\
538\end{array}$} & $533,540,554,538,542,599$ \\
\hline & & & 526 \\
\hline $\begin{array}{c}\text { Cinara (Cinara) piceicola } \\
\mathrm{n}=7\end{array}$ & \multirow{6}{*}{$\begin{array}{c}\text { C. }(\text { C. }) \text { piceicola } \\
521,703,704,705,706,707 \\
708 \\
\text { C. }(\text { C. }) \text { pilicornis } \\
709,712,714,711,713,566 \\
710 \\
\text { C. (C.) pruinosa } \\
527,746,745,744,741,531, \\
742,743 \\
\text { C. (C.) brauni }\end{array}$} & $\begin{array}{c}521,707,706,705,704,703 \\
708\end{array}$ & \multirow{3}{*}{$\begin{array}{c}\text { C. }(C .) \text { piceicola } \\
521,703,704,705,706,707 \\
708 \\
\text { C. }(\text { C. }) \text { pilicornis } \\
709,712,714,711,713,566 \\
710 \\
\end{array}$} \\
\hline & & $709,711,714,712$ & \\
\hline $\begin{array}{l}\text { Cinara (Cinara) pilicornis } \\
\qquad \mathrm{n}=7\end{array}$ & & $710,713,566$ & \\
\hline \multirow{2}{*}{$\begin{array}{c}\text { Cinara } \\
\qquad \mathrm{n}=8\end{array}$} & & $527,746,745$ & $\begin{array}{c}744,745,746,741,531,742 \\
743\end{array}$ \\
\hline & & $744,741,531,742,743$ & 527 \\
\hline Cinara (Cinara) brauni & & $555,674,670,675,671,673$ & C. (C.) brauni \\
\hline
\end{tabular}




\begin{tabular}{|c|c|c|c|}
\hline \multirow[t]{2}{*}{$\mathrm{n}=8$} & \multirow{12}{*}{$\begin{array}{c}\text { 536, 555, 670, 671, 672, 673, } \\
\text { 674, 675 } \\
\text { C. }(C .) \text { hyperophila } \\
\text { 553, 686, 687, 689, 690, 684, } \\
524,682,683,685 \\
\text { C. }(\text { C. }) \text { neubergi } \\
\text { 604, 606, 610, 613, 669, 693, } \\
\text { 694, 695, 691, 692 } \\
\text { C. }(C .) \text { pilosa } \\
\text { 612, 715, 716, 717, 522, 611, } \\
718 \\
\text { C. }(C .) \text { pinea } \\
720,722,723,725,608,719 \\
721,724 \\
\text { C. }(C .) \text { piniphila } \\
736,605,530,551,737,738, \\
739,603,607,609,734,735, \\
740 \\
\text { C. }(C .) \text { nuda } \\
\text { 525, 701, 700, 699, 696, 698, } \\
702 \\
\text { C. }(C .) \text { pini } \\
733,529,568,730,732,728, \\
731,727,726,729 \\
769\end{array}$} & 672 & \multirow{9}{*}{$\begin{array}{c}536,555,670,671,672,673, \\
674,675 \\
\text { C. }(C .) \text { hyperophila } \\
553,686,687,689,690,684, \\
524,682,683,685 \\
\text { C. }(C .) \text { neubergi } \\
604,606,610,613,669,693, \\
694,695,691,692 \\
\text { C. }(C .) \text { pilosa } \\
\text { 612, 715, 716, 717, 522, 611, } \\
718 \\
\text { C. }(C .) \text { pinea } \\
720,722,723,725,608,719, \\
721,724 \\
\text { C. }(C .) \text { piniphila } \\
736,605,530,551,737,738, \\
739,603,607,609,734,735, \\
740\end{array}$} \\
\hline & & 536 & \\
\hline $\begin{array}{c}\text { Cinara (Cinara) hyperophila } \\
\mathrm{n}=10\end{array}$ & & $\begin{array}{c}524,682,685,683,684,553 \\
687,690,689,686\end{array}$ & \\
\hline $\begin{array}{l}\text { Cinara (Cinara) neubergi } \\
\mathrm{n}=10\end{array}$ & & $\begin{array}{c}669,610,613,604,606,694 \\
693,695,691,692\end{array}$ & \\
\hline \multirow{2}{*}{ Cinara $($ Cinara $)$ pilosa $\mathrm{n}=7$} & & $717,612,716,715$ & \\
\hline & & $611,718,522$ & \\
\hline \multirow{2}{*}{$\begin{array}{l}\text { Cinara }(\text { Cinara }) \text { pinea } \\
\mathrm{n}=8\end{array}$} & & $\begin{array}{c}\text { Cinara }(C .) \text { pinea } \\
720,723,725,722 \\
\text { C. }(C .) \text { piniphila } \\
736\end{array}$ & \\
\hline & & $\begin{array}{c}\text { Cinara }(C .) \text { pinea } \\
608,719,721,724 \\
\text { C. }(C .) \text { piniphila } \\
530,551,603,607,609,734 \\
735,737,738,739,740\end{array}$ & \\
\hline $\begin{array}{l}\text { Cinara (Cinara) piniphila } \\
\mathrm{n}=13\end{array}$ & & 605 & \\
\hline $\begin{array}{c}\text { Cinara (Cinara) nuda } \\
\mathrm{n}=7\end{array}$ & & $\begin{array}{c}525,701,700,699,696,698, \\
702\end{array}$ & $\begin{array}{c}525,696,698,701,702,699, \\
700\end{array}$ \\
\hline $\begin{array}{c}\text { Cinara (Cinara) pini } \\
\qquad \mathrm{n}=10\end{array}$ & & $\begin{array}{c}733,529,568,730,732,728 \\
731,727,726,729\end{array}$ & $\begin{array}{c}529,568,733,726,727,728, \\
729,730,731,732\end{array}$ \\
\hline Cinara (Schizolachnus) obscura & & & C. (S.) obscurus \\
\hline $\mathrm{n}=5$ & $569,775,759,761$ & $569,1 / 2,159, / 01,109$ & $769,569,759,761$, \\
\hline $\begin{array}{c}\text { Cinara (Schizolachnus) pineti } \\
\mathrm{n}=8\end{array}$ & $\begin{array}{c}768,570,763,766,767,764, \\
762,765\end{array}$ & $\begin{array}{c}768,570,763,766,767,764 \\
762,765\end{array}$ & $\begin{array}{c}775 \\
C .(S .) \text { pineti } \\
570,762,763,764, \\
765,766,767,768\end{array}$ \\
\hline $\begin{array}{l}\text { Eulachnus agilis } \\
\mathrm{n}=5\end{array}$ & $\begin{array}{c}\text { Eulachnus agilis } \\
539,545,565,534,770\end{array}$ & $539,545,565,534,770$ & $\begin{array}{l}534,565,770,539 \\
545 \\
\end{array}$ \\
\hline $\begin{array}{l}\text { Eulachnus rileyi } \\
\mathrm{n}=4\end{array}$ & $\begin{array}{c}\text { Eulachnus rileyi } \\
776,774,760,777\end{array}$ & $776,774,760,777$ & $760,774,776,777$ \\
\hline Eulachnus brevipilosus $\mathrm{n}=5$ & $552,546,772,773,547$ & $552,546,772,773,547$ & $\begin{array}{l}552,546,547,772 \\
773\end{array}$ \\
\hline $\begin{array}{l}\text { Eulachnus nigricola } \\
\qquad \mathrm{n}=1\end{array}$ & 537 & 537 & 537 \\
\hline
\end{tabular}




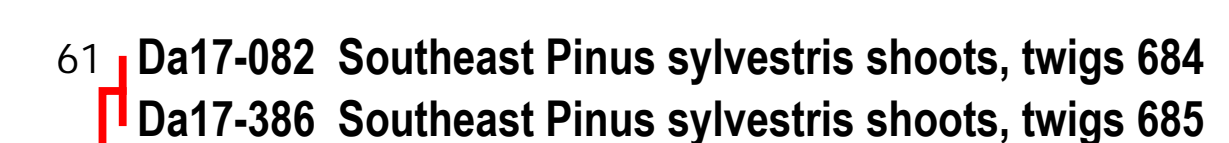

Da17-351 Coastal Pinus sylvestris shoots, twigs 687

Da17-714 Coastal Pinus sylvestris shoots, twigs 553

6. Da18-457 MidLith Pinus sylvestris shoots, twigs 682

52 [Da17-109 Midith Pamogitian Pinus sylvestris shoots, twigs 524

Da17-331 Coastal Pinus sylvestris shoots, twigs 686

—Da18-53 Southea-283 Samogitian Pinus sylvestris shoots, twigs 688

12 HA03711 Coastal Pinus nigra shoots twigs 55

$100\left[\begin{array}{l}\text { Ra18-14 Samogitian Pinus aff. nigra shoots } 670 \\ \text { Ra18-5 MidLith Pinus aff. nigra shoots } 672\end{array}\right.$

52 Da17-320 Coastal Pinus aff. nigra shoots, twigs 536 Da18-321 MidLith Pinus aff. nigra shoots, twigs 671
- Da18-350 MidLith Pinus aff. nigra shoots, twigs 673

Da18-298a Southeast Pinus aff nigra shoots tws 673

Da17-311 MidLith Pinus mugo shoots 604

Da17-356A Coastal Pinus mugo shoots 606
Da17-436B Southeast Pinus mugo shoots 610

Da17-515B Coastal Pinus mugo shoots 613

100 Ra18-10 Samogitian Pinus sp. shoots 669

Da18-363 MidLith Pinus mugo shoots 691

Da18-301 Southeast Pinus mugo shoots 693

Da18-293 Samogitian Pinus mugo shoots 695

Da18-451 Southeast Pinus sylvestris shoots 710

Da18-202 Midlith Pinus sylvestris shoots 716

Da18-177 Southeast Pinus sylvestris shoots 715
Da17-485 Southeast Pinus sylvestris shoots 611

Da16-032 Southeast Pinus sylvestris shoots 522
Da17-510 Southeast Pinus sylvestris shoots 612

$98\left[\begin{array}{l}\text { Da17-212 Samogitian Pinus sylvestris shoots } 723 \\ \text { Da18-52 Southeast Pinus sylvestris shoots } 724\end{array}\right]$ C inara (C inara) pinea

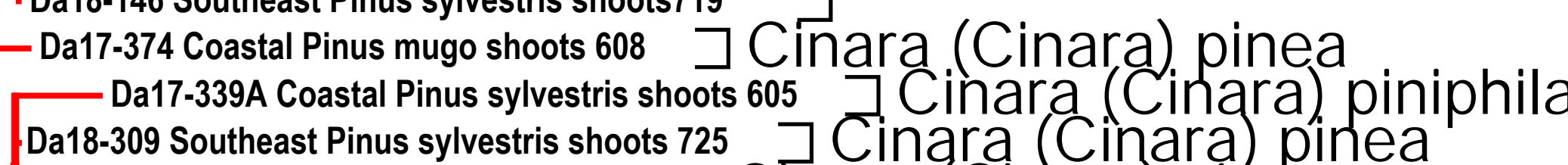

100

Da18-309 Southeast Pinus sylvestris shoots 725 C Cina ra (CC ina ra) pinea

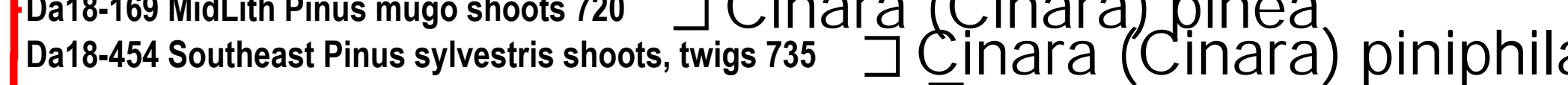

C inara (C inara) piniphila

Da18-130 Samogitian Pinus sylvestris shoots 722$]$ C inara (C inara) pinea

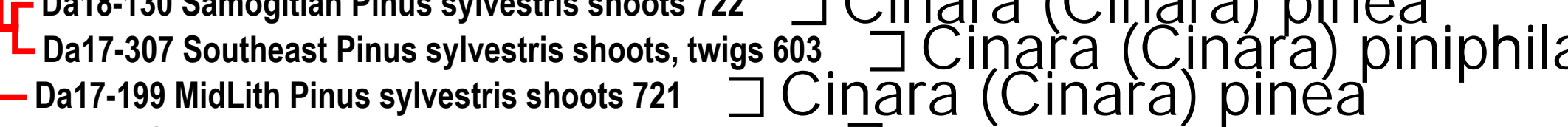

Da17-698 Coastal Pinus sylvestris shoots, twigs 559

Da17-376 Coastal Pinus mugos shoots, twigs 609

(18-436 Coastal Pinus sylvestris shoots, twigs $737 \quad$ inara (C inara) piniphila

Da18-134 Samogitian Pinus sylvestris shoots, twigs 730

Da18-325 Coastal Pinus sylvestris shoots, twigs 736

Da17-355 Coastal Picea abies branches 745

Da17-172 Southeast Picea abies branches 743

Da17-441b Southeast Picea abies twigs, branches $742 \quad$ C inara (C inara) pruinosa

1 Da16-355 Midlith Picea abies bigs, branches 74

Da17-215 Samogitian Picea abies branches 744

D16-087 Samogitian Picea abies branches, 744

Da17-076 Southeast Picea abies twigs 703

Dat7-1598 Southeast Picea abies shoots, twigs 705

Da17-091 Southeast Picea abies twigs 521

Da17-214 Samogitian Picea abies shoots. wwigs 707

Da17-322b Coastal Picea monticena shoots, twigs 700

-187 MidLith Picea abies shoots, twigs 706
Da17-196 MidLith Picea abies shoots 712

- Da17-509a Southeast Picea abies shoots 710

63 Da17-440a Southeast Picea abies shoots 709

Da17-171 Southeast Picea abies shoots 711

- Da17-322a Coastal Picea monticena shoots 713

Da17-549 Southeast Picea abies shoots 714

Da18-139 Southeast Pinus sylvestris shoots, twigs
Da18-19 Southeast Pinus sylvestris twios 732

Da17-345 Coastal Pinus sylvestris twigs 731 .

Da18-389 MidLLith Pinus sylvestris shoots, twigs 728

Da18-170 MidLith Pinus mugo shoots, twigs 727

Da17-424 Southeast Pinus sylvestris shoots, twigs 733

Dat

Da16-016 Southeast Pinus sylvestris shoots

Da17-208 Samogitian Pinus sylvestris shoots, twigs 729

Da18-71 Midlith Pinus sylvestris shoots, twits

100 Da17-328 Coasta Phas sllestis stem 690

Da17-425 Southeast Pinus sylvestris stem 698

Da17-443 Southeast Pinus sylvestris stem 699
Da17-470 MidLith Pinus sylvestris stem, branches 701
Da18-13 Southeast Pinus sylvestris branches 702

Da17-445 MidLith Picea abies stem 542
Dat

Da17-715 Coostal Picea omorika twigs 554
Da17-353 Coastal Picea abies branches 540

Da17-347 Coastal Picea abies stem, branches 538

Da17-227 Coastal Picea abies stem, branches 533
Ra06-10a Southeast Taxus baccata stem

Ra06-10a Southeast Taxus baccata stem, bran

Cinara (C inara) piceicola

Cinara (C inara) pilicornis

C inara (C inara) pini

Cinara (C inara) nuda

Cinat

Cinara (C inara) piceae

-Da17-684 Southest Larix decidu bresces 500

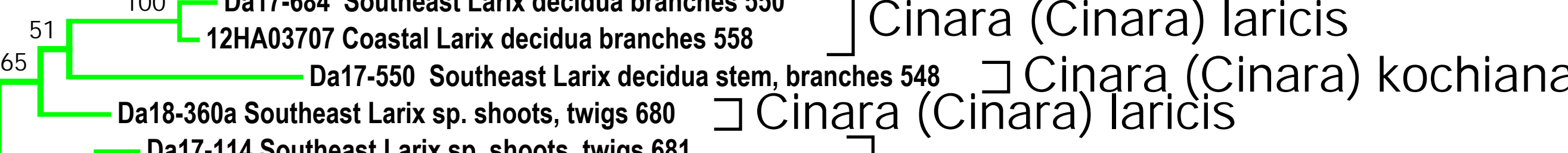

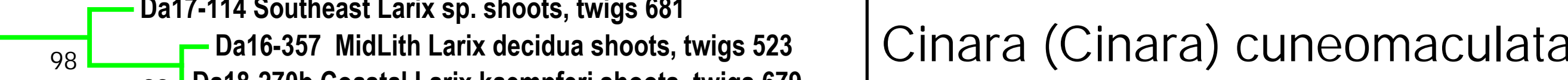

99 Da18-270b Coastal Larix kaempferi shoots, twigs 679

Da18-258b Coastal Pinus nigra needles 761

Da18-254b Coastal Pinus aff. nigra needles 775 C inara (S chizolachnus) obscurus

Da17-318 Midlith Pinus nigra needles $569^{\circ}$

[Da18-298b Southeast Pinus aff. nigra needles 767

Da17-330 Coastal Pinus sylvestris needles 768

57 Da17-457 Southeast Pinus sylvestris needles 570

Da18-151 MidLith Pinus sylvestris needles 704
Da18-317b MidLith Pinus mugo needles 765

Da17-3016 Southeast Pinus sylvestris needllo

Da17-384 Coastal Picea abies twigs 678

100 Da17-204 Samogitian Picea abies twigs 677 C inara (C inara) costata

${ }_{92}^{100}$ Da17-186b MidL

Cinara (S chizolachnus) pineti

${ }_{66}$\begin{tabular}{|l} 
Da17-462 Southeast Pinus sylvestris needles \\
Da18-369b Southeast Pinus mugo needles 770
\end{tabular}

${ }_{99} 12 \mathrm{HA} 03889$ Southeast Pinus sylvestris needles $565 \quad$ E ulachnus agilis

100 Da17-312 MidLith Pinus sylvestris needles 534

Da18-458a MidLith Pinus sylvestris needles 776

E ulachnus rileyi

59 Da18-369c Southeast Pinus mugo needles 777
$7-324$ Coastal Pinus heldreichii needles 537
J E ulachnus nigricola

Da17-524 Coastal Pinus sylvestris needles 546
Da17-528A Coastal Pinus sylvestris needles 547

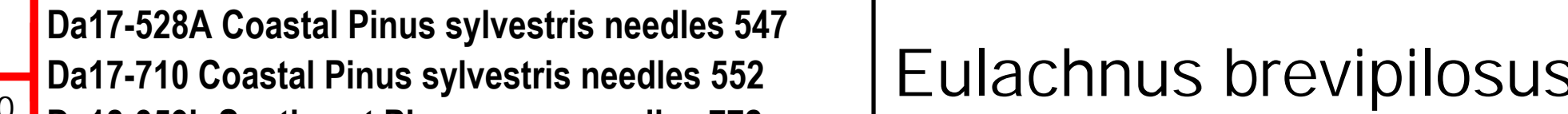

100 Da17-710 Coastal Pinus sylvestris needles 552

7-446 Midlith Abies koreana shoots s43 $\lrcorner$ J

${ }_{00}^{\text {Da17-427 Southeast Juniperus communis root collar 541 }}$

Da17-028 Southeast Juniperus communis branches, stem 532

Da17-213 Samogitian Thuja occidentalis twigs 748

Da17-232 Coastal Thuja occidentalis twigs 747

17 HA04521 MidLith Thuja occidentalis shoots 564
17 A04527 Midd ith Juniperus virgininn shoots 503

17 A04522 Midlith Juninerus communis shoots 562

94 Da17-296 Southeast Juniperus communis shoots 751

Da18-41 Southeast Juniperus communis shoots 755

${ }^{100}{ }^{60}$ Da17-92 Southeast Juniperus communis shoots 750

Da16-078 Samogitian Juniperus communis shoots 520

${ }_{61}^{74}$ Da18-285 Samogitian Juniperus communis shoots 756

Cinara (C upressobium) mordvilkoi

Cinara (C upressobium) cupressi

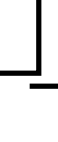

C inara (C upressobium) juniperi 


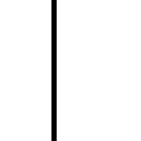

